\title{
Retrofitting a thermoelectric-based solar still integrated with an evacuated tube collector utilizing an antibacterial-magnetic hybrid nanofluid
}

\author{
Gholamabbas Sadeghi ${ }^{\text {a }}$, Saeed Nazari ${ }^{\text {b,* }}$ \\ ${ }^{a}$ Department of Thermal and Fluid Engineering, Faculty of Engineering Technology (ET), University of Twente, 7500 AE Enschede, the Netherlands \\ ${ }^{\mathrm{b}}$ Department of Mechanical Engineering, Faculty of Engineering, Razi University, Kermanshah, Iran
}

\section{H I G H L I G H T S}

- Empirical enhancing the efficiency of a thermoelectric cooling channel solar still

- Utilizing an antibacterial-magnetic nanofluid to retrofit the solar desalination

- Integrating the modified solar still with a concentrating evacuated tube collector

- Regarding different volume concentrations of $\mathrm{Ag} @ \mathrm{Fe}_{3} \mathrm{O}_{4} /$ deionized water nanofluid

- Comparative economic and payback period analyses of the modified solar still

\section{A R T I C L E I N F O}

\section{Keywords:}

Solar still

Thermoelectric cooling channel solar still Antibacterial-magnetic Ag@ $\mathrm{Fe}_{3} \mathrm{O}_{4} /$ deionized water hybrid nanofluid

Productivity

Energy efficiency

\section{G R A P H I C A L A B S T R A C T}

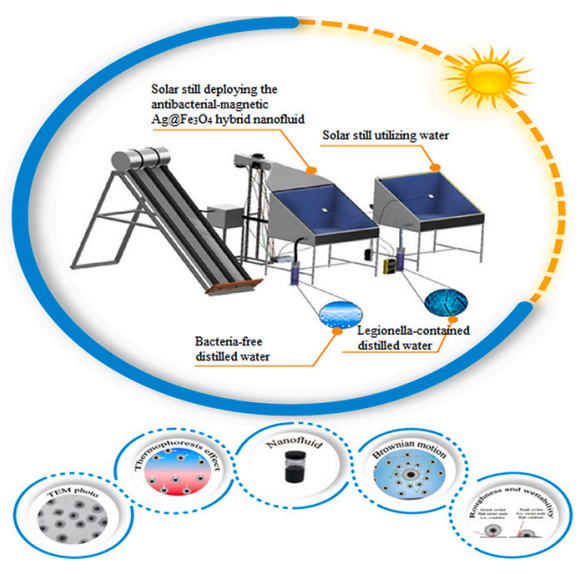

\begin{abstract}
A B S T R A C T
Providing sufficient potable water using solar energy is a promising method; however, existence of legionella bacteria, causing pneumonia is prevalent in the solar systems operating at low temperature range, such as solar stills. This work is the first report of applying the antibacterial property of a hybrid nanofluid for disinfection, and using its magnetic property for increasing the heat transfer rate, simultaneously. In this research, the performance of a modified single slope solar still using a thermoelectric-equipped channel integrated with a concentrating evacuated tube collector applying an antibacterial-magnetic $\mathrm{Ag} @ \mathrm{Fe}_{3} \mathrm{O}_{4} /$ deionized water hybrid nanofluid was examined experimentally, and was compared to that of a traditional solar still. The results indicated that both productivity and energy efficiency were improved by integrating the thermoelectric cooling channel solar still with the concentrating solar collector and adding $\mathrm{Ag} @ \mathrm{Fe}_{3} \mathrm{O}_{4}$ nanoparticles to the fluid. The modified solar still integrated with the solar collector utilizing the proposed hybrid nanofluid at a volume concentration of $0.08 \%$ ameliorates the daily productivity and energy efficiency rates by respectively $218 \%$ and $117 \%$ compared to a traditional solar still. Also, the cost of producing freshwater by the proposed modified solar still is about $0.019\left(\$ / \mathrm{L} / \mathrm{m}^{2}\right)$ and the payback period was calculated as 369 days.
\end{abstract}

\footnotetext{
* Corresponding author.

E-mail address: Saeed_Nazari1367@yahoo.com (S. Nazari).
} 


\begin{tabular}{|c|c|c|c|}
\hline \multicolumn{2}{|c|}{ Nomenclature } & $\mathrm{u}(\eta)$ & Energy efficiency uncertainty value \\
\hline \multicolumn{2}{|l|}{ Symbols } & $\mathrm{W}_{\mathrm{TM}}$ & Power consumption of thermoelectric (W) \\
\hline $\mathrm{A}_{\mathrm{c}}$ & The concentrating collector area $\left(\mathrm{m}^{2}\right)$ & \multirow{2}{*}{\multicolumn{2}{|c|}{ Acronyms }} \\
\hline $\mathrm{A}_{\mathrm{ss}}$ & The solar still basin area $\left(\mathrm{m}^{2}\right)$ & & \\
\hline ATC & Annual total cost $(\$)$ & CETC & Concentrating evacuated tube collector \\
\hline AFC & Annual fixed cost $(\$)$ & DW & Deionized water \\
\hline AMC & Annual maintenance cost (\$) & FPSC & Flat plate solar collector \\
\hline ARV & Annual return value $(\$)$ & HNF & Hybrid nanofluid \\
\hline a & Equipment accuracy & HNP & Hybrid nanoparticle \\
\hline CPL & Cost per liter $\left(\$ \mathrm{~L}^{-1} \mathrm{~m}^{-2}\right)$ & $\mathrm{h}$ & Hour \\
\hline RCF & Return capital factor & $\mathrm{L}$ & Liter \\
\hline $\mathrm{CF}$ & Cash flow (\$) & $\mathrm{mL}$ & Milliliter \\
\hline $\mathrm{f}$ & Inflation rate & MSS & Modified solar still \\
\hline$h_{f g}$ & Evaporation enthalpy @ $\mathrm{T}_{\mathrm{f}}\left(\mathrm{J} \mathrm{kg}^{-1}\right)$ & NF & Nanofluid \\
\hline I & Solar radiation intensity $\left(\mathrm{W} \mathrm{m}^{-2}\right)$ & PCM & Phase change material \\
\hline $\mathrm{i}$ & Annual interest rate & ppm & Parts per million \\
\hline \multirow{2}{*}{$\dot{m}_{e v}$} & Desalinated water per hour $\left(\mathrm{kg} \mathrm{m}^{-2}\right)$ & PTC & Parabolic trough collector \\
\hline & & $\mu \mathrm{S} / \mathrm{cm}$ & Microsiemens per centimeter \\
\hline$\left(\dot{m}_{e v}\right)$ & Desalinated water per day $\left(\mathrm{kg} \mathrm{m}^{-2}\right)$ & $\mathrm{t}$ & Time $(s)$ \\
\hline $\mathrm{n}_{\mathrm{TM}} / d$ & Number of thermoelectric modules & SS & Solar still \\
\hline $\mathrm{n}_{\mathrm{f}}$ & Number of fans & TDS & Total dissolved solids \\
\hline $\mathrm{N}$ & Number of annual sunny days & $\mathrm{TM}$ & Thermoelectric module \\
\hline $\mathrm{P}$ & Cost of system materials (\$) & TEM & Transmission electron microscope \\
\hline PBT & Payback period (Day) & TCC & Thermoelectric cooling channel \\
\hline RFF & Recession fund factor & TSS & Traditional solar still \\
\hline $\mathrm{r}$ & Solar still longevity (year) & TCCSS & TCC solar still \\
\hline $\mathrm{R}$ & Return value after system longevity (\$) & ICETCTC & CSS Integrated CETCTCCSS \\
\hline$S_{\mathrm{p}}$ & Cost of water in Iran $\left(\$ \mathrm{~L}^{-1}\right)$ & $\mathrm{VF}$ & Volume fraction of nanoparticles \\
\hline $\mathrm{T}_{\mathrm{f}}$ & Temperature of fluid (K) & $\mathrm{W}$ & Water \\
\hline $\mathrm{T}_{\mathrm{b}}$ & Temperature of basin $(\mathrm{K})$ & $\mathrm{XRD}$ & X-ray diffraction \\
\hline $\mathrm{T}_{\mathrm{g}}$ & Temperature of glass (K) & & \\
\hline$\Delta \mathrm{T}$ & Temperature difference $(\mathrm{K})$ & Greek let & ers \\
\hline$\Delta \mathrm{T}_{\mathrm{f}-\mathrm{g}}$ & Fluid-glass temperature difference $(\mathrm{K})$ & $\eta$ & Energy efficiency of the solar still \\
\hline$\Delta \mathrm{T}_{\mathrm{m}}$ & The maximum $\Delta \mathrm{T}_{\mathrm{f}-\mathrm{g}}(\mathrm{K})$ & $\eta_{d}$ & Daily energy efficiency \\
\hline $\mathrm{u}$ & Standard uncertainty of a parameter & $\alpha$ & Contact angle \\
\hline
\end{tabular}

\section{Introduction}

The phrases "solar energy", "fresh water", and "Nano Energy" generically evoke sustainability, liveliness, and cutting-edge technology. Many scientists have implemented nanotechnology so as to thermally retrofit various energy systems and power generation plants; such as solar cells, fuel cells, batteries, and electric generators [1-5]. On the other hand, having considered only about $1 \%$ of the whole water resources as the available fresh water [6], obliges the human beings to reflect on finding new environmentally-friendly approaches to distillation of brine and supplying fresh water needs. For this purpose, a certain amount of energy to distil brine is essential. This energy can be provided either electrically or by use of the solar energy. In order to avoid emission of the greenhouse gases such as carbon dioxide, utilizing the solar energy is by far preferable [7-9]. Solar stills (SSs) are reassuring candidates at this point, which are comprised of a sloped glass cover, a basin to hold the brine, insulated side walls, and a frame. Their performance usually enhances through decreasing the cover temperature for a heat loss reduction and/or raising the basin water temperature for an evaporation rate increase. Many researches have been conducted on improving the performances of passive SSs [10-13].

Shanmugan et al. [14] coated the basin surface with the $\mathrm{TiO}_{2}$ and $\mathrm{Cr}_{2} \mathrm{O}_{3}$ nanomaterial leading to presenting the energy efficiency of 57.1\% during summer time. Abdullah et al. [15] revealed that using a rotating drum inside the basin can enhance the evaporation area and could increase the daily SS productivity up to $6420 \mathrm{~mL} / \mathrm{m}^{2}(217 \%$ more than that of a traditional solar still). Thalib et al. [16] investigated the effect of using nanoparticles and phase change materials (PCMs) inside the tubular solar stills. The results showed that the solar still using the paraffin wax and the solar still utilizing the paraffin wax mixed with graphene nanoparticles presented daily productivities of 6 and $7.9 \mathrm{~kg} /$ $\mathrm{m}^{2}$, respectively. M.A.Porta-Gándara et al. [17] injected air bubbles into the basin water in an SS to perturb the water. This approach caused augmentation of the evaporation area leading to a $12 \%$ solar still productivity enhancement. Nazari et al. [18] integrated a single slope SS with a thermoelectric cooling channel (TCC) using the $\mathrm{Cu}_{2} \mathrm{O}$ nanofluid (NF) in the basin. They used a fan to lead the superfluous vapor between the basin fluid and the cover to the cooling channel. This vapor was cooled and condensed as the freshwater in the back of SS. The results demonstrated that using the TCC and employing the $\mathrm{Cu}_{2} \mathrm{O}$ NF in the modified solar still (MSS) enhance the productivity up to $38.5 \%$ and $82.4 \%$, respectively. Shoeibi et al. [19] exploited the simultaneous cooling and heating effects of thermoelectric modules (TMs) in enhancing the efficiency of an SS. They used the cooling affect for cooling the cover and used the hot side of thermoelectric modules to contribute to heating the basin water. The efficiency of this MSS was reported as $76 \%$ and its productivity enhanced up to 2.3 times more than a similar traditional solar still (TSS). Kabeel et al. [20] experimentally investigated the effects of hollow circular fins at the basin as well as using PCMs on the productivity of an SS with a pyramid-shaped cover. They utilized the PCM in order to store the solar energy during sunshine and use it after the sunset to prolong the SS productivity duration. The 
daily amount of productivity for the TSS, the non-PCM fin-based SS, and the fin-based SS using PCM were acquired as $4,5.75$ and $8.1 \mathrm{~L} / \mathrm{m}^{2} /$ day, respectively. Panchal et al. [21] came to this conclusion that there is not much difference between inclined and vertical fins in the absorber of an SS and both of them increase the SS productivity up to $25 \%$. Zanganeh et al. [22,23] improved the productivity of an SS through coating the condensation part (glass cover) with the silicon and titanium dioxide nanomaterials. They concluded that using the nano-based coated covers leads to changing the condensation mechanism from a film-wise to a drop-wise manner. The results showed that the SS productivity for a non-coated cover and a silicon-based coated cover are $4.82 \mathrm{~L} / \mathrm{m}^{2} /$ day and $5.8 \mathrm{~L} / \mathrm{m}^{2} /$ day, respectively. Nazari et al. [24] could enhance the energy efficiency of a thermoelectric cooling channel solar still (TCCSS) up to $80 \%$ using a TM-based cooling duct, at 0.08 volume fraction of $\mathrm{Cu}_{2} \mathrm{O}$ /water NF. Balachandran et al. [25] examined the effect of using cooked oil at the bottom of basin chamber in order to raise its temperature leading to a more SS productivity. It was concluded that the productivities of TSS and oil cooked-based MSS were $3 \mathrm{~L} / \mathrm{m}^{2} /$ day and 3.77 $\mathrm{L} / \mathrm{m}^{2} /$ day, successively. Parsa et al. [26] investigated the impacts of silver NF in an SS with TMs inside the basin (first system), and an SS with TMs inside the basin as well as using a double-slope condenser at the back of SS (second system). One side of the condenser was cooled by TMs and the other slope was cooled by a pumped water film to find out which cooling method provides a more productivity. The electrical energy for running the whole system was supplied by photovoltaic panels. The results indicated that the first and the second system increased the daily productivity and the daily efficiency of a TSS up to $50 \%, 30 \%, 100 \%$ and $27 \%$, respectively. There also have been several studies on the active SSs integrated with the solar collectors to supply the hot basin water [27].

Abbaspour et al. [28] attached an ETC to an SS to enable it to absorb more beam radiation. They also used a vacuum pump to create a vacuum situation inside the SS. The results indicated the lower the pressure of system inside, the higher the productivity of SS. M. Fathy et al. [29] integrated an SS with the fixed and tracking types of parabolic trough collectors (PTCs). The results showed that the SS integrated with tracking PTC presents respectively about $28 \%$ and $140 \%$ more productivity than that of the SS integrated with a non-tracking PTC, and that of a TSS. Mahian et al. [30] integrated an SS with two series of flat plate collectors connected to a heat exchanger positioned at the bottom of basin. They investigated the impacts of NFs and water depth on the MSS performance. It was concluded that using NF passing through the solar heating system is an advantage provided by the temperature is above $70{ }^{\circ} \mathrm{C}$ and in this case, the productivity can be raised up to two times compared to that of an SS without a heat exchanger. Shehata et al. [31] integrated an SS with an ETC using ultrasonic humidifiers, PCMs, and reflectors. They also applied a photovoltaic panel to supply the power for running the humidifiers. The findings revealed that regarding an SS integrated with an ETC, applying humidifiers is more beneficial than utilizing PCMs. The maximum yield of the SS integrated with an ETC using humidifiers is about $2 \mathrm{~kg}$ more than that of the same active solar system employing PCMs. W. Sharshir et al. [32] enhanced the efficiency of an SS integrated with an ETC using two types of NFs, namely carbon black and copper oxide. The results illustrated that the use of carbon black presents about 7\% more efficiency compared to the copper oxide. Alwan et al. [33] applied a rotating cylinder at various speeds $(0.5,1$, and $3 \mathrm{rpm}$ ) to augment the evaporation area and used a flat plate solar collector to increase the basin water temperature. The results demonstrated that using the rotational cylinder at the lowest speed and integrating the solar collector to the MSS (containing the cylinder) lead to $161 \%$ and $292 \%$ SS productivity enhancement, respectively compared to a TSS with daily yield of $1.4 \mathrm{~L} / \mathrm{m}^{2} /$ day. Panchal et al. [34] experimentally indicated that the productivities for a TSS, an SS integrated with a 14-tubes ETSC, and an SS integrated with the same ETSC and using calcium pieces of stone are $2.48,5.09$, and $5.31 \mathrm{~L} / \mathrm{m}^{2} /$ day, respectively. The maximum basin temperature reached $87^{\circ} \mathrm{C}$ using the ETSC and calcium stones were utilized as the sensible heat storage material. In 2020, Madiouli et al. [35] surveyed the simultaneous impacts of flat plate solar collector, parabolic trough collector, and layers of ball glass as the sensible heat storage material on the productivity of a TSS in summer and winter seasons. Water was used as the working fluid for the flat plate collector and oil was utilized for running the parabolic trough one, both of which were connected to the SS through a serpentine heat exchanger in the basin. Moreover, the layers of ball glass were placed under the heat exchanger at the bottom of basin in order to let the solar desalination system keep operation during night hours. The results illustrated that through this method of SS modification, the values of productivities for the TSS were enhanced up to $203 \%$ and $172 \%$ in summer and winter, successively. Furthermore, the cost analysis showed that the cost of $1 \mathrm{~L}$ of freshwater increased about 3.3 times compared to the TSS potable water production per liter. Most of the mentioned works are focused on increasing the condensing rate, or augmentation of the heat transfer rate for obtaining more evaporation rates. However, very few of the presented papers investigated the existence of pestilential microorganisms inside the produced freshwater. Using antibacterial fluids is a reassuring approach to making sure of the health of SSs consumers.

Scant attention has been paid to the quality and taste of distilled water. With accordance to the literature, there exist two published papers on using antibacterial silver-based NFs in the SSs, up to now $[26,36]$. In addition, it was proved that the thermal behavior of a silvermagnetite hybrid nanofluid (HNF) is better than that of a sole silverbased NF [37]. The novelty of this work is simultaneous employment of magnetic and antibacterial properties for an $\mathrm{HNF}\left(\mathrm{Ag} @ \mathrm{Fe}_{3} \mathrm{O}_{4} /\right.$ deionized water $\mathrm{HNF}$ ) at different volume fractions (0.04 and $0.08 \mathrm{VF}$ ) as well as integrating a concentrating evacuated tube collector (CETC) using a compound parabolic concentrator with a TCCSS to provide hot basin fluid to enhance the solar system productivity. In this multifunctional research, a TCC containing four TMs has been adopted to produce cooled air channeled on the glass cover to reduce the glass temperature leading to a rise in the evaporation rate. Ultimately, the performance of integrated concentrating evacuated tube collector thermoelectric cooling channel solar still (ICETCTCCSS) at various operational conditions was investigated and compared to that of a TSS.

\section{2. $\mathrm{Ag} @ \mathrm{Fe}_{3} \mathrm{O}_{4} /$ deionized water hybrid nanofluid procedures}

\subsection{Preparation}

In the first place, the magnetite $\mathrm{Fe}_{3} \mathrm{O}_{4}$ nanoparticles were synthesized; then, the proposed $\mathrm{Ag} @ \mathrm{Fe}_{3} \mathrm{O}_{4} /$ deionized water $\left(\mathrm{Ag} @ \mathrm{Fe}_{3} \mathrm{O}_{4} / \mathrm{DW}\right)$ HNF was synthesized through a two-step method. So as to prepare the magnetic $\mathrm{Fe}_{3} \mathrm{O}_{4}$ nanoparticles, the aqueous solution of iron chloride (III) and iron chloride (II) with a $0.5 \mathrm{~mol}$ fraction (i.e. $4 \mathrm{mM} \mathrm{FeCl}_{3}$ and $2 \mathrm{mM}$ $\mathrm{FeCl}_{2}$ ) were dissolved in $50 \mathrm{~mL}$ of deionized water as the base fluid. After $10 \mathrm{~min}$ of stirring and obtaining a homogeneous solution, the reaction temperature was enhanced up to $90{ }^{\circ} \mathrm{C}$ as well as $2.5 \mathrm{~mL}$ of $25 \%$ ammonia solution was added to the previous solution in a drop-scale manner over $40 \mathrm{~min}$ in order to precipitate the magnetite nanoparticles. The acquired reactive nanocomposite was allowed to possess the atmospheric temperature. Then, it was stirred for 15 min through a magnetic stirrer (model RH Digital White) and its red-brown color converted to black. Next, the obtained black nanocomposite went through a low speed centrifugation at $2000 \mathrm{rpm}$ and the top liquid was thrown away. The remained sediment was neatly washed with distilled water and ethanol several times. Ultimately, the sediment was dried by a freeze dryer (model Scientz-10 N) to achieve the iron oxide $\left(\mathrm{Fe}_{3} \mathrm{O}_{4}\right)$ nanoparticles.

Furthermore, both $\mathrm{Fe}_{3} \mathrm{O}_{4}$ and silver nitrate $\left(\mathrm{AgNO}_{3}\right)$ particles were dissolved in deionized water as the base fluid. Then, a surfactant named polyvinylpyrrolidon (PVP) was added to the solution for giving the steric effect to the nanoparticles and the mixing was stirred well with the magnetic stirrer. Next, $2.5 \mathrm{~mL}$ of $25 \%$ ammonia solution was added to 
the solution. After that, the solution was placed under an ultrasound vibrator with $60 \mathrm{kHz}$ frequency for $25 \mathrm{~min}$. Then, the sodium borohydroxide solution was added in a drop-by-drop way and the acquired solution was again placed under the same ultrasonic vibrator for $25 \mathrm{~min}$.

\subsection{NF stability}

Stability of NFs is the most significant factor to ensure the effectiveness of utilized NF in the thermal behavior improvement of systems. Even though some researches have theoretically proved that aggregation of nanoparticles leads to enhancement of a NF thermal conductivity using a fractal method; however, this is subject to the fractal aggregated nanoparticles distribution (chain-like shape) [38]. Since it is not certain what kind of shape the aggregated nanoparticles might take, it is assumed that agglomeration of nanoparticles causes a reduction in the NF thermal conductivity leading to the system performance deterioration. Fig. 1 (a) demonstrates the steric effect that PVP brings about around each nanoparticle to not let clogging occurs. In fact, the PVP causes each nanoparticle exerts repulsive forces to the surrounding particles to avoid agglomeration. Fig. 1 (b) shows the stability of prepared NF within six months after preparation, which implies reliability of the results of present study implemented one day after the proposed HNF preparation. Fig. 1 (c) illustrates the schematic of dispersed versus aggregated nanoparticles in the base fluid over time.

\subsection{1. $\mathrm{Ag} @ \mathrm{Fe}_{3} \mathrm{O}_{4} /$ deionized water hybrid nanofluid characterization}

So as to identify the morphology and structure of proposed HNF, Xray diffraction (XRD), Scanning Electron Microscopy (SEM), and Transmission Electron Microscopy (TEM) analyses have been conducted. Fig. 2 shows the XRD image to identify the crystal structure, crystal phase, crystal size, and orientation of $\mathrm{Ag} @ \mathrm{Fe}_{3} \mathrm{O}_{4}$ nanoparticles. An XRD device model Inlet was utilized so as for analysis of the nanoparticles morphology. The peaks on $38^{\circ}, 44^{\circ}$, and $64^{\circ} 2 \theta$ angles are corresponding to the standard $\mathrm{Ag}$ peaks. Accordingly, the peaks in the $2 \theta$ region $\left(30.1^{\circ}\right.$, $35.7^{\circ}, 43.2^{\circ}, 53.5^{\circ}, 56.9^{\circ}$, and $62.6^{\circ}$ ) are pertaining to the standard peaks of magnetite. Fig. 3 (a) indicates the SEM image of proposed nanoparticles using a MIRA3 TE Scan SEM machine, which illustrates a 20-30 nm average size as well as the spherical shape of $\mathrm{Ag} @ \mathrm{Fe}_{3} \mathrm{O}_{4}$ nanoparticles. Fig. 3 (b) represents the TEM image of $\mathrm{Ag} @ \mathrm{Fe}_{3} \mathrm{O}_{4}$ nanoparticles utilizing a device model Philips CM10 at100kV acceleration voltage. As it can be observed, each nanoparticle has a core and shell structure. The $20-25 \mathrm{~nm}$ thickness silver forms the nanoparticle's core surrounded by the $5-10 \mathrm{~nm}$ thickness of magnetite, which is forming the nanoparticle's shell.

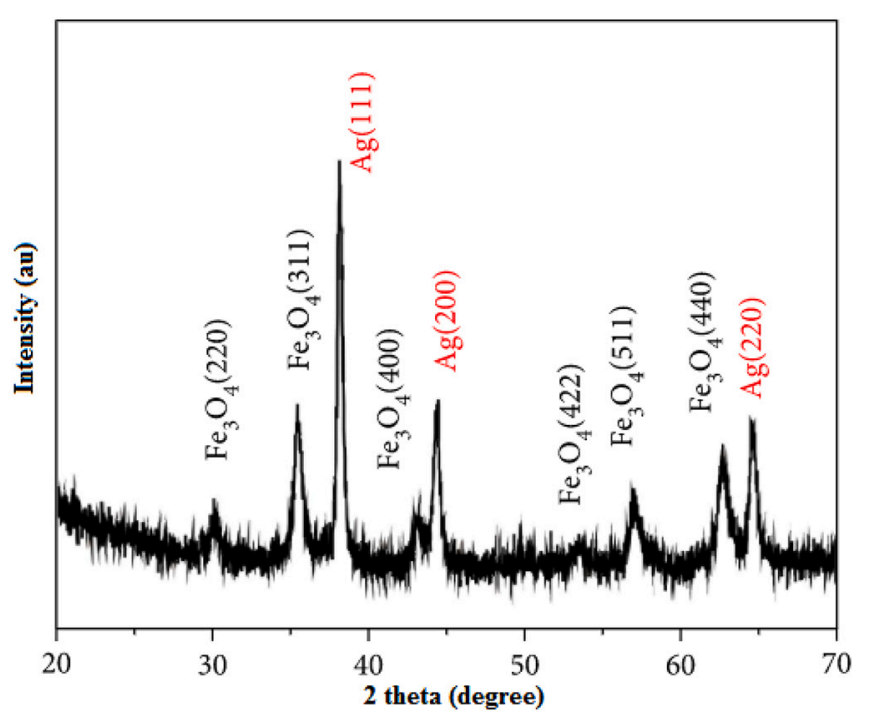

Fig. 2. Image of the XRD test related to the $\mathrm{Ag} @ \mathrm{Fe}_{3} \mathrm{O}_{4}$ nanoparticles.

\section{Experimental apparatus}

\subsection{Setup explanations}

In the present research, both TSS and TCCSS were made of a $1.5 \mathrm{~mm}$ sheet of steel. The tanks of both types of SSs were covered with black jutes of $80 \mathrm{~cm}$ length and $62.5 \mathrm{~cm}$ width in order to absorb the highest amount of solar radiation. In the TCCSS, the inner walls have been covered by mirrors $2 \mathrm{~mm}$ in thickness to let some radiation hitting the walls, reach the fluid surface. The glass covers, which are of $4 \mathrm{~mm}$ thicknesses, were sloped on the SSs at the same angle as the latitude of region, in which the experiments have been conducted $\left(35^{\circ} \mathrm{N}\right)$ leading to absorption of the most perpendicular radiation. The shortest and the longest heights of SSs were 12 and $55 \mathrm{~cm}$, respectively. The basin was covered by a rough sack painted black to absorb more heat, and the outer walls of SSs were well insulated with an elastomeric material of 9 $\mathrm{mm}$ thickness. The edges of glass covers have been completely sealed by silicone to prevent the vapor inside the SS leaking out. The materials and the dimensions of both TSS and TCCSS were the same; however, the TCCSS is equipped with a fan and a TCC, which have been positioned at the top of glass leading to cooling the sloped cover. Regarding the TCC, there is a fan at the inlet of channel vacuuming the air into the channel at
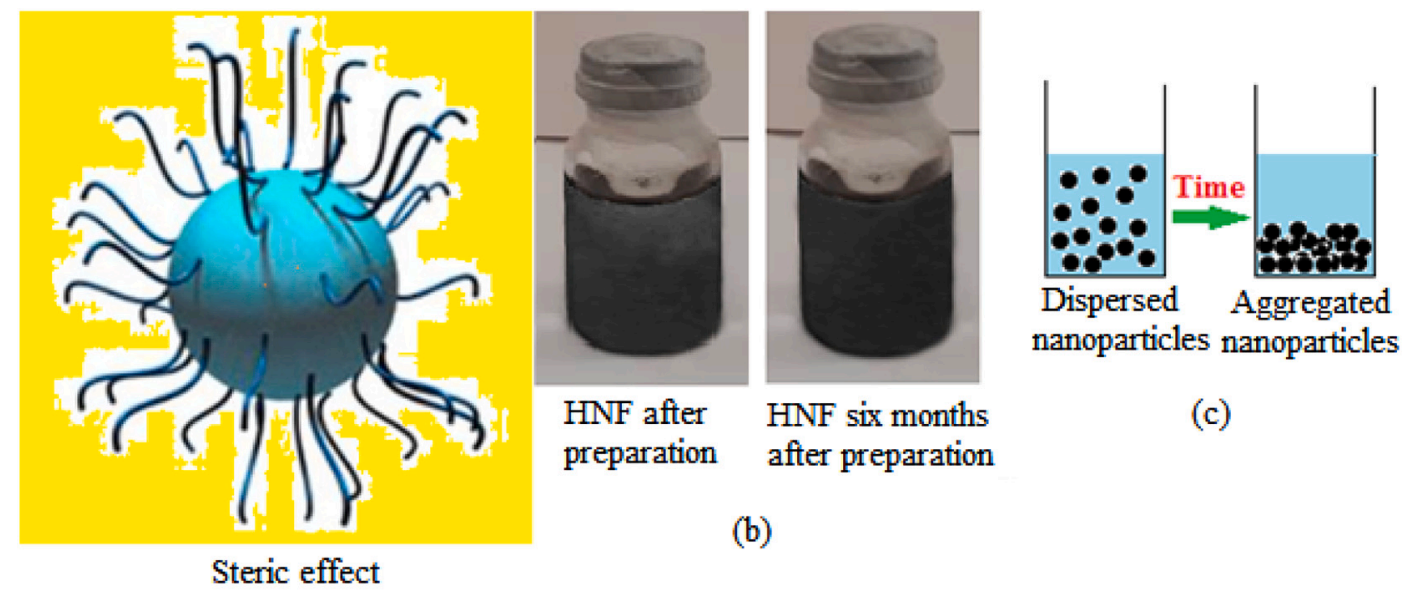

$\mathrm{HNF}$ after preparation after preparation nanoparticles nanoparticles

(c)

(a)

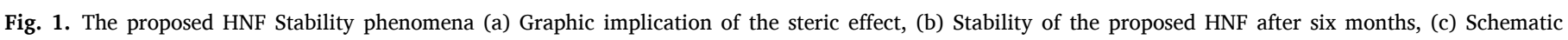
indication of the clogging of nanoparticles. 


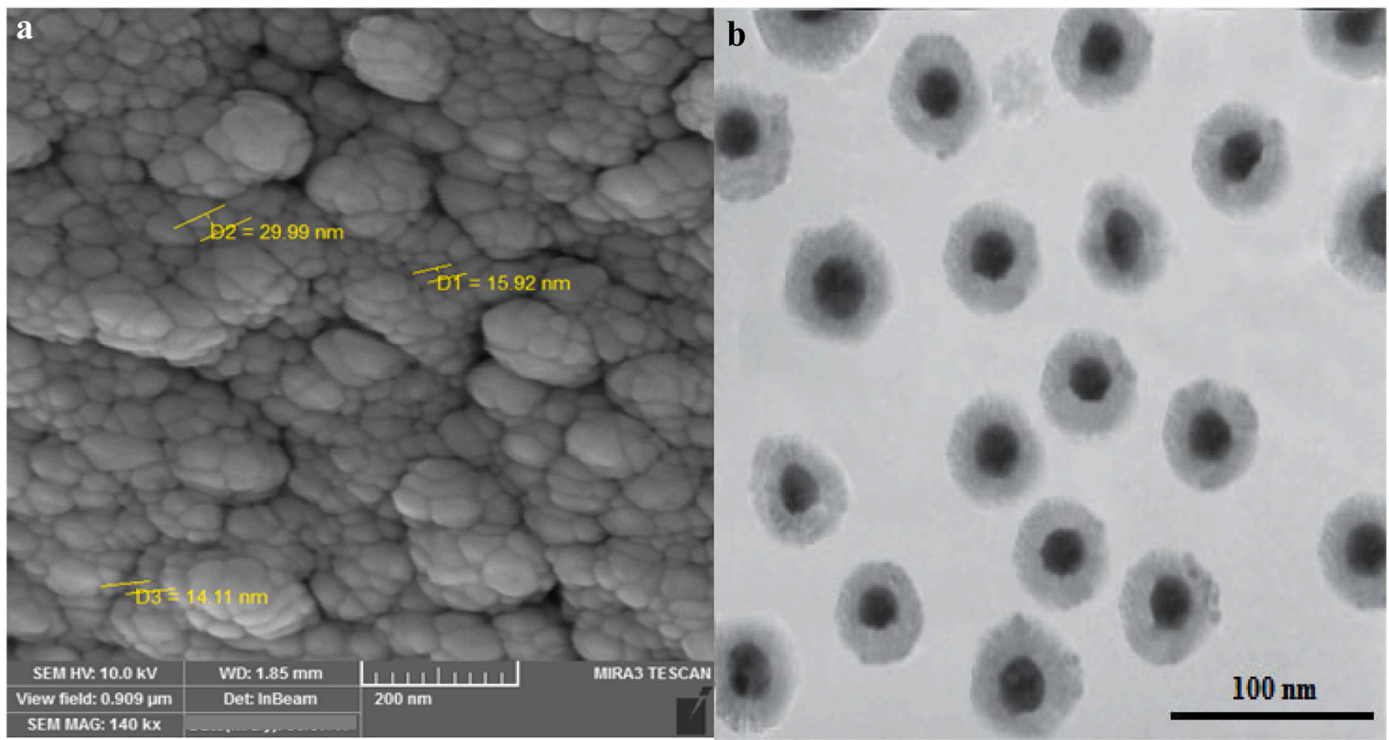

Fig. 3. The morphology tests of the proposed $\mathrm{Ag} @ \mathrm{Fe}_{3} \mathrm{O}_{4} \mathrm{HNPs}$ (a) SEM image (b) TEM image.

1-Glass cover

2- Thermoelectric cooling

channel

3- Thermoelectric module

4- Sucker fan

5-Galvanized inlet cold air intake

6-Data logger

7-Distelled water collector

8-Floater

9- Parabolic concentrator

10- Evacuated tube

11- Thermal storage tank

12-Solar collector frame

13- Thermoelectric cooling channel stand

14- Solar meter

15- Modified solar still

16- Conventional solar still

17- Power supply

18- Solar still stand

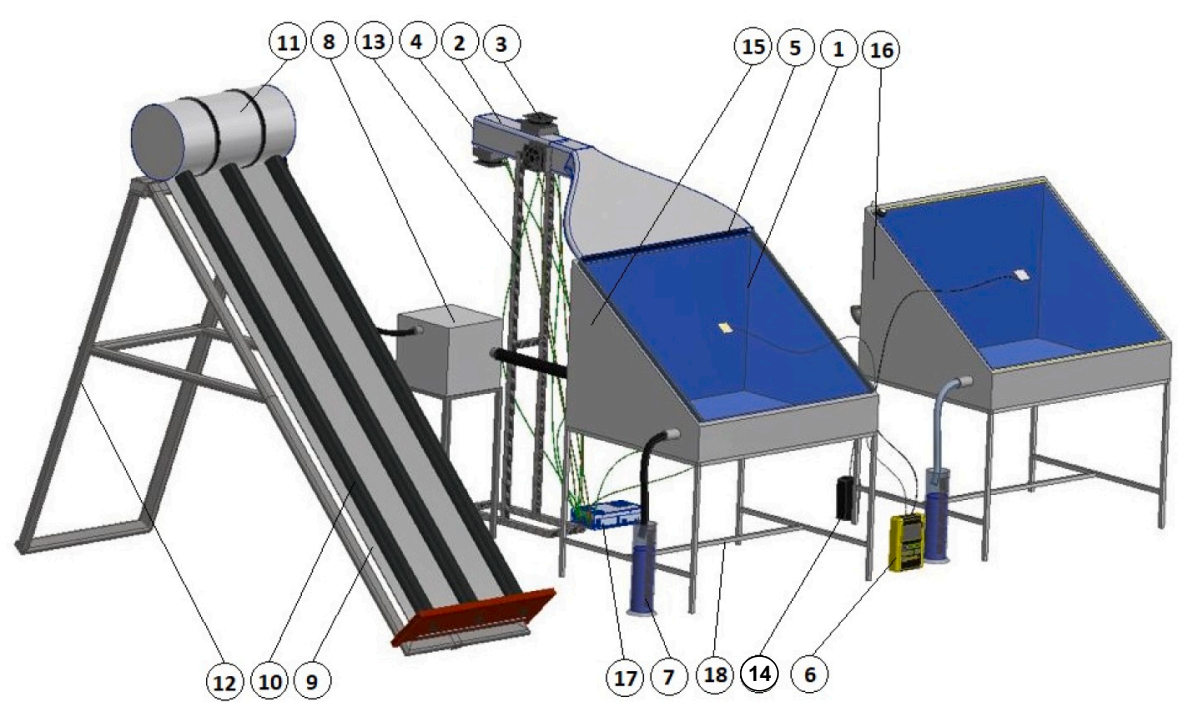

Fig. 4. Schematic of the experimental apparatus. 
a certain velocity; the air becomes cool after having contact with the cooling channel; the cooled air blows on the glass by means of another fan installed at the end of the cooling channel being operated at the same velocity as the former fan. Hence, the temperature of glass reduces, which contributes to the productivity improvement. Four cooling TMs (TM 12706) were placed on the channel, which were stuck to the channel by a pulpy silicone material causing the coldness of channel's inner surfaces. The hot sides of TMs were attached to the aluminum heat sinks and the fans aimed at cooling the heat sinks. The set of TMs, heat sinks, and fans were firmly attached to the channel by some galvanized braces. The important point is that the TMs consume low electricity; thus, they are quite economically favorable [39]. On the other hand, the galvanized sheets of channel have been welded to one another through the spot cold welding method to enhance the cooling area of cooling channel. Inside the SS, the basin fluid vaporized, and was distilled after having contact with the glass. Then, the distilled water was conducted to a chute, and poured into a graduated container.

Moreover, so as to take advantage of the TCCSS performance, the $\mathrm{Ag} @ \mathrm{Fe}_{3} \mathrm{O}_{4} / \mathrm{DW}$ HNF was utilized instead of brackish water as the basin fluid in two states. In the first state, the effect of different volume fractions of the nanoparticles on the performance of TCCSS was investigated. In the second state, the proposed HNF was initially applied to a CETC in order to receive the heat energy up to reaching high temperatures. Then, the heated HNF flows into the TCCSS through the set of insulated pipes and an intermediate tank. The CETC was comprised of three WGETSC evacuated tubes, a steel frame positioned at $45^{\circ}$, a curved mirror as the compound parabolic concentrator to concentrate as much possible as beam and diffused types of solar radiations on the tubes, and a storage tank made of galvanized steel. Fig. 4 demonstrates the schematic of ICETCTCCSS amid all components. On the basis of the literature, the aspect ratio of CETCs ought to be about $57 \mathrm{~L} / \mathrm{m}^{2}$ in order to present the highest performance [8]. Hence, according to the collector surface in this project $\left(0.35 \mathrm{~m}^{2}\right)$, the designed storage tank volume was obtained as $20 \mathrm{~L}$. To avoid leakage of the working fluid in the attachment region of the tubes to the tank, rubbers as well as silicone materials were applied for sealing. There also exists an insulated intermediate tank between the CETC and the TCCSS made of galvanized steel, which has a floater valve in order to adjust the hot outlet of the CETC, and control the TCCSS basin fluid level. Fig. 5 illustrates the apparatus of second round of experiments (the constructed ICETCTCCSS), in the present study.

\subsection{Implementation of experiments}

All the data have been gathered at Kermanshah, one of the best places for operating solar systems in west of Iran [40] with geographical conditions of $34^{\circ} \mathrm{N}$ and $47^{\circ} \mathrm{E}$ in July 2019 from 10 am to $5 \mathrm{pm}$. In the start of each experiment, the basin fluid depth was considered as a

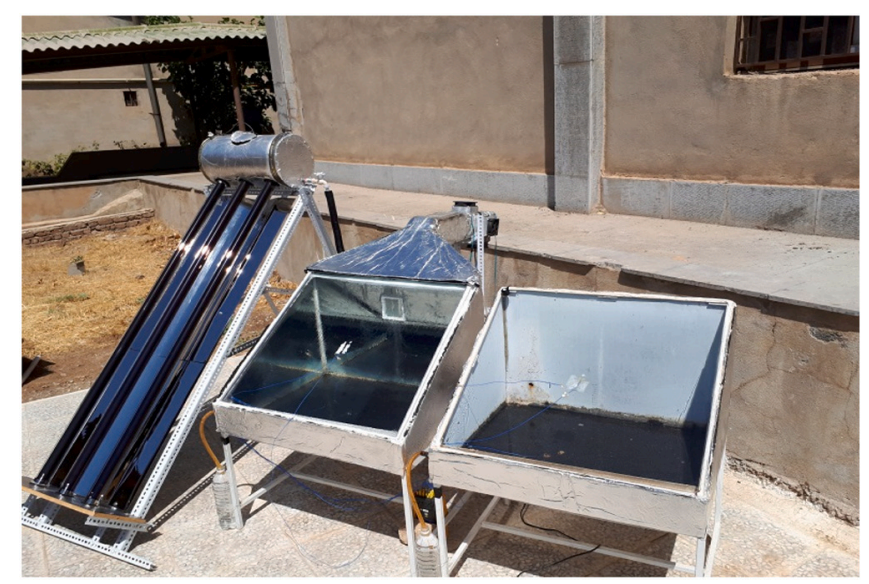

Fig. 5. Image of the constructed TSS, and the ICETCTCCSS. constant value of $3 \mathrm{~cm}$, which is equivalent to $15 \mathrm{~L}$. The working fluid was separately heated inside the CETC for several days. Moreover, at the beginning of each day, the CETC was operated until 10 am to preheat the fluid, and provide the TCCSS with sufficiently hot inlet fluid.

So as to determine the performance of SSs, the parameters, such as the wind velocity, the solar irradiance, the outlet fluid temperature of CETC, the cover temperature, the basin temperature, the basin fluid temperature, the productivity, and the energy efficiency were measured. Ten K-type thermocouples with a $0.1{ }^{\circ} \mathrm{C}$ measurement accuracy calibrated by a platinum resistance thermometer were utilized to record the aforementioned temperatures attached to a Lutron Model data logger. The required electric power to run the fans and thermoelectric modules were supplied by a converting AC $220 \mathrm{~V}$ to DC $12 \mathrm{~V}$ power supply. As for solar radiation evaluation, a TES 132 Model solar meter was used. An AVM 305 Model anemometer manufactured by PROVA Company was utilized to assess the velocity of wind around the SSs. Furthermore, the potential of hydrogen $(\mathrm{pH})$ and the total dissolved solids (TDS) of distilled water were investigated through an EDZO 5011 Model pH meter and an inoLab Cond Level 2 electrical conductivity meter to ensure the liability of produced potable water. It ought to be mentioned that the electrical conductivity of distilled water was registered in terms of $\mu \mathrm{S} / \mathrm{cm}$ and then converted into ppm using the Lenntech calculator to find the hardness of distilled water.

\section{Equations}

\subsection{Efficiency of system}

The hourly energy efficiencies of SSs are obtained from [24]:

$\eta=\frac{\dot{m}_{e v} A_{s s} h_{f g}}{\left[I A_{s s}+n_{T M} W_{T M}+n_{f} W_{f}\right] \times t}$

Moreover, in case of an ICETCTCCSS, this parameter is acquired by [18]:

$\eta=\frac{\dot{m}_{e v} A_{s s} h_{f g}}{\left[I\left(A_{s s}+A_{c}\right)+n_{T M} W_{T M}+n_{f} W_{f}\right] \times t}$

in which $t$ is assumed as $300 \mathrm{~s}$, the amounts of solar radiations on the SSs and the CETC are considered as I. In addition, the latent heat is given by [24]:

$h_{f g}=\left(2501.9-2.40706 T_{f}+1.92217 \times 10^{-3} T_{f}^{2}-1.5863 T_{f}^{3}\right) \times 10^{3}$

The experimental investigations have been carried out within $7 \mathrm{~h}$ a day from 9:00 am to 5:00 pm. Hence, the daily energy efficiencies of SSs are calculated through:

$\eta_{d}=\frac{\sum_{i=1}^{7} \dot{m}_{e v} A_{s s}\left(2501.9-2.40706 T_{f}+1.92217 \times 10^{-3} T_{f}^{2}-1.5863 T_{f}^{3}\right) \times 10^{3}}{\sum_{i=1}^{7}\left[I\left(A_{s s}+A_{c}\right)+n_{T M} W_{T M}+n_{f} W_{f}\right] \times t}$

\subsection{Economic analysis of the proposed solar still}

When economy of an SS appears for investigations, three critical factors are of great significance: adequate strength of the materials consumed in constructing the SS, cost effectiveness of constructing the SS, and reasonability of productivity with respect to the utilized materials. Therefore, the economic analysis of a constructed SS cannot be overlooked. For this purpose a funding evaluation of the ICETCTCCSS has been conducted as follows:

The cost of producing $1 \mathrm{~L}$ of distilled water is obtained from [18]: 
$C P L=\frac{A T C}{\left(\dot{m}_{e v}\right)_{d} N}$

in which ATC is defined as [18]:

$A T C=A F C+A M C-A R V$

where $A F C$ is [18]:

$A F C=P \times R C F$

in which $R C F$ is calculated by [18]:

$R C F=\frac{i(1+i)^{r}}{(1+i)^{r}-1}$

Moreover, we have the following correlations [18]:

$A M C=0.15 A F C$

$A R V=S \times R F F$

$R F F=\frac{i}{(1+i)^{r}-1}$
$C F=\left(\dot{m}_{e v}\right)_{d} N S_{p}$

in which $S_{p}$ is the price of $1 \mathrm{~L}$ of distilled water in the country of origin (Iran) considered as \$ 0.1.

\subsection{Uncertainty investigation}

Calculation of the uncertainties is intrinsic to experimental studies. An engineer ought to know about the uncertainty values of obtained data to ensure that they can be applied to design procedures. As a whole, the uncertainties are generally divided into two various categories; random errors and systematic ones. In this study, an even distribution of data is assumed; hence, the first type of uncertainty has not been regarded. The standard uncertainty of parameters can be presented through the following equation [18]:

$u=\frac{a}{\sqrt{3}}$

Moreover, the uncertainty relating to the efficiency of SSs can be derived from [18]:

$u(\eta)=\eta\left(\frac{u^{2}\left(\dot{m}_{e v}\right)}{\dot{m}_{e v}^{2}}+\frac{u^{2}(I)}{\left(I+\frac{n_{T M} W_{T M}}{A_{s s}+A_{c}}+\frac{n_{f} W_{f}}{A_{s s}+A_{c}}\right)^{2}}+\frac{u^{2}\left(W_{T M}\right)}{\left(\frac{I\left(A_{s s}+A_{c}\right)}{n_{T M}}+W_{T E M}+\frac{n_{f} W_{f}}{n_{T M}}\right)^{2}}+\frac{u^{2}\left(W_{f}\right)}{\left(\frac{I\left(A_{s s}+A_{c}\right)}{n_{f}}+\frac{n_{T M} W_{T M}}{n_{f}}+W_{f}\right)^{2}}\right)^{1 / 2}$

$R=0.2 P$

where $\mathrm{R}$ is the value of system after its longevity. Table 1 shows the cost of each material used in the proposed ICETCTCCSS.

One of the key factors in designing and implementing SSs, is the payback period (PBP) defined as the period after operation, in which the main cost will be returned. The PBP can be acquired by the following equation [41]:

$P B P=\frac{\ln \left(1-\frac{P(i-f)}{C F}\right)}{\ln \left(\frac{1+f}{1+i}\right)}$

where $\mathrm{f}$ is the inflation rate in Iran, which considered as 0.3. In addition, the cash flow can be obtained from [18]:

Table 1

Cost of materials for constructing the proposed ICETCTCCSS.

\begin{tabular}{lc}
\hline Material & Cost (\$) \\
\hline Galvanized sheet used for the TCCSS & 50 \\
Galvanized sheet used for the cooling channel & 8 \\
Glass cover & 3 \\
Elastomeric insulation & 12 \\
Thermoelectric modules & 18 \\
Heat sinks & 10 \\
Fans & 20 \\
Power supply & 18 \\
Nanofluid preparation & 50 \\
Thermal storage tank of the CETC & 10 \\
Evacuated tubes & 12 \\
Parabolic concentrator (curved mirror) & 13 \\
Frame of the CETC & 5 \\
Consumed electric power $(\mathrm{kW} / \mathrm{h})$ & 0.01 \\
\hline
\end{tabular}

The uncertainties of measurement devices as well as the energy efficiencies of SSs are indicated in Table 2.

\section{Results and discussions}

In this section, the efficacy of proposed synthesized HNF in enhancing the heat transfer rate leading to an increase in the evaporation rate has been discussed. Next, the thermal characteristics of investigated six cases have been analyzed. Then, an economic analysis has been conducted in order to ensure the cost-effectiveness of proposed ICETCTCCSS. Finally, the effectiveness of constructed ICETCCSS has been demonstrated compared to that of the previous similar studies. The examined six types of SSs are explained as follows:

$\gg$ Case 1: TSS

$>$ Case 2: TCCSS using water as the working fluid

$>$ Case 3: TCCSS using $\mathrm{Ag} @ \mathrm{Fe}_{3} \mathrm{O}_{4} / \mathrm{DW}$ HNF at $0.04 \mathrm{VF}$ as the working fluid

$>$ Case 4: TCCSS using $\mathrm{Ag} @ \mathrm{Fe}_{3} \mathrm{O}_{4} / \mathrm{DW}$ HNF at $0.08 \mathrm{VF}$ as the working fluid

Table 2

Uncertainty values for the devices and performance parameters.

\begin{tabular}{llll}
\hline Equipment & Accuracy & Range & Standard uncertainty \\
\hline Thermocouples & $\pm 1{ }^{\circ} \mathrm{C}$ & $-150-1000{ }^{\circ} \mathrm{C}$ & $0.6{ }^{\circ} \mathrm{C}$ \\
Solar meter & $\pm 1 \mathrm{~W} / \mathrm{m}^{2}$ & $0-2000 \mathrm{~W} / \mathrm{m}^{2}$ & $0.6 \mathrm{~W} / \mathrm{m}^{2}$ \\
Anemometer & $\pm 0.1 \mathrm{~m} / \mathrm{s}$ & $0.5-50 \mathrm{~m} / \mathrm{s}$ & $0.06 \mathrm{~m} / \mathrm{s}$ \\
$\mathrm{pH}$ meter & $\pm 0.01 \mathrm{pH}$ & $0-14 \mathrm{pH}$ & $0.006 \mathrm{pH}$ \\
TDS meter & $\pm 1 \mathrm{ppm}$ & $0-2000 \mathrm{ppm}$ & $0.6 \mathrm{ppm}$ \\
Humidity meter & $\pm 0.1 \mathrm{RH}$ & $10-98 \% \mathrm{RH}$ & $0.06 \mathrm{RH}$ \\
Graded container & $\pm 10 \mathrm{~mL}$ & $0-1 \mathrm{~L}$ & $2.5 \mathrm{~mL}$ \\
Energy efficiency & \pm 0.01 & $0-100 \%$ & $\pm 0.25 \%$ \\
\hline
\end{tabular}




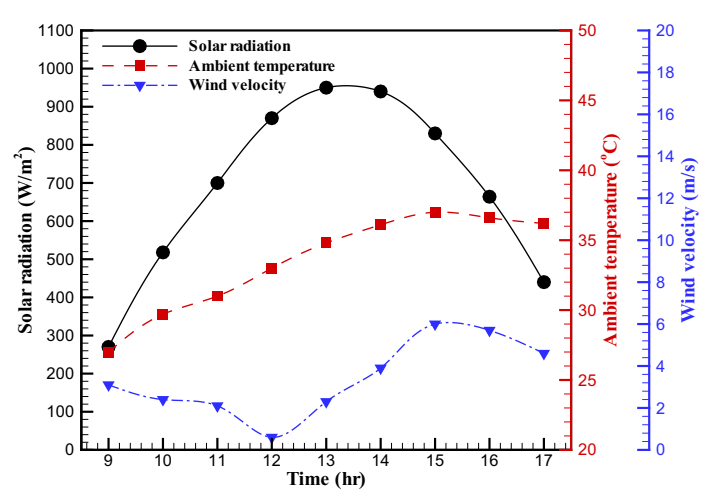

Fig. 6. Variation of climatic conditions, such as solar radiation, ambient temperature, and wind velocity during the days of experimentations, on an average basis.

$>$ Case 5: ICETCTCCSS using water as the working fluid

$>$ Case 6: ICETCTCCSS using $\mathrm{Ag} @ \mathrm{Fe}_{3} \mathrm{O}_{4} / \mathrm{DW} \mathrm{HNF}$ at $0.08 \mathrm{VF}$ as the working fluid

\subsection{Environmental conditions}

Fig. 6 indicates the average climatic conditions variations during the days of experiments. As shown in this illustration, the ambient temperature varies proportional to the change of solar radiation amount. The highest solar radiation is recorded around solar noon, and the highest amount of ambient temperature was observed roughly $2 \mathrm{~h}$ after the solar noon. It is because the Earth initially absorbed the radiation, and around 2:30 pm to 3:00 pm has reflected some of the absorbed radiation leading to increasing the temperature of surroundings. In addition, the average wind velocity is changing within 0.5 to $6 \mathrm{~m} / \mathrm{s}$ during the experiments.

\subsection{Experimental analysis}

\subsubsection{On the role of $\mathrm{Ag} @ \mathrm{Fe}_{3} \mathrm{O}_{4} /$ deionized water hybrid nanofluid}

In this section, the impact of $\mathrm{Ag} @ \mathrm{Fe}_{3} \mathrm{O}_{4} / \mathrm{DW} \mathrm{HNF}$ at 0.04 and 0.08 volumetric fractions on the temperature variations of different components and the performances of all cases has been thoroughly investigated. In fact, there exist some phenomena, which cause an increase in the NF assistance in the evaporation rate indicated in Fig. 7. The Thermophoresis effect is stated as the migration of nanoparticles from a high temperature area to a low temperature zone [42]. Through this effect, the $\mathrm{Ag} @ \mathrm{Fe}_{3} \mathrm{O}_{4}$ nanoparticles tend to move from the basin to the fluid surface. Then, the viscosity of HNF around the basin surface would reduce and the thickness of boundary layer decreases leading to an enhancement in the heat transfer rate from the basin to the fluid. Moreover, the Brownian motion in NFs, which was first introduced in
1827 [43], is defined as dispersedly random motion of nanoparticles in the base fluid as a result of colliding with other nanoparticles and molecules of the base fluid [44]. This random motion of nanoparticles leads to a micro-scale increase in the NF convective heat transfer coefficient [45]. Furthermore, as an inherent property, the contact angle $(\alpha)$ of a NF is less than that of water, which implies more wettability of NFs in comparison with water leading to a higher heat transfer rate for the NFs [46]. In addition, the surface roughness is another factor contributing to the heat transfer rate. Wenzel showed that enhancing the surface roughness leads to increasing the fluid wettability (reducing $\alpha$ ) [47]. Additionally, in 2010, Gloss and Herwig demonstrated that the degree of surface roughness cannot be neglected in the heat transfer analysis of laminar flows [48]. This is the reason behind choosing a piece of sack at the bottom of basin, in the present study.

\subsubsection{Temperature variation}

Fig. 8 indicates the influence of adding nanoparticles to the base fluid (water) over temperature variations of the main SSs components, such as the basin surface $\left(\mathrm{T}_{\mathrm{b}}\right)$, the basin fluid $\left(\mathrm{T}_{\mathrm{f}}\right)$, the glass cover $\left(\mathrm{T}_{\mathrm{g}}\right)$, and values of the fluid-glass temperature difference $\left(\Delta \mathrm{T}_{\mathrm{f}-\mathrm{g}}\right)$ throughout the day from 9:00 am to 5:00 pm as to all under study cases. Fig. (a) and (b) indicate that $T_{b}$ and $T_{f}$ related to xCase 6:o employing the TCC, which leads to reducing $\mathrm{T}_{\mathrm{g}}$. Fig. 8 (c) illustrates that the cases 2 and 5 present a lower $T_{-} g$ compared to that of case 1 . The term $\Delta T_{f-g}$ is one of the fundamental factors in denoting the SS efficacy, such that the more this temperature difference, the higher the productivity and the thermal efficiency of SS will be. Nonetheless, the evaporation and condensation processes take a certain amount of time to occur. Hence, the maximum hourly productivity and efficiency happen with a delay. As demonstrated in Fig. 8 (d), the highest values of $\Delta \mathrm{T}_{\mathrm{f}-\mathrm{g}}$ have been observed at 1:00 pm; whereas, Fig. 8 (a), (b), and (c) showed that the highest $\mathrm{T}_{\mathrm{b}}, \mathrm{T}_{\mathrm{f}}$, and $\mathrm{T}_{\mathrm{g}}$ regarding all cases were registered at 2:00 pm, which is exactly after the most intensive solar radiation. This phenomenon is because after 1:00 pm (the peak of solar radiation) the basin absorbs a lot of heat energy and its temperature climbs leading to an increase in $T_{f}$ through convection between the basin and fluid. Moreover, the radiative heat transfer between the fluid and the glass also augments leading to a reduction in $\Delta \mathrm{T}_{\mathrm{f}-\mathrm{g}}$ at 2:00 pm compared to that at 1:00 pm.

Table 3 indicates the values of different components temperatures, on an hourly basis. It can be seen that in case $1, \Delta \mathrm{T}_{\mathrm{f}-\mathrm{g}}$ varies within 0.01 to $3.9^{\circ} \mathrm{C}$. Regarding case 2 , the TCC brings about a remarkable reduction in $\mathrm{T}_{\mathrm{g}}$ leading to a decrease in $\mathrm{T}_{\mathrm{f}}$, subsequently. Nonetheless, the parameter $\Delta \mathrm{T}_{\mathrm{f}-\mathrm{g}}$ increases so that it differs from 0.2 to 8.2 , which is roughly $4{ }^{\circ} \mathrm{C}$ higher than that of case 1 . With respect to case 3 , in which $\mathrm{Ag} @ \mathrm{Fe}_{3} \mathrm{O}_{4} / \mathrm{DW} \mathrm{HNF}$ at 0.04 volume concentration is employed, $\mathrm{T}_{\mathrm{f}}$ augments due to both the Brownian motion mechanism and obtaining more capability in absorption of light. Also, $\mathrm{T}_{\mathrm{g}}$ rises; however the amount of $\Delta \mathrm{T}_{\mathrm{f}-\mathrm{g}}$ is vacillating between $0{ }^{\circ} \mathrm{C}$ at 9:00 am and $9.1{ }^{\circ} \mathrm{C}$ at 5:00 pm. Moreover, the highest $\mathrm{T}_{\mathrm{f}}($ at $2: 00 \mathrm{pm})$ is about $9.8^{\circ} \mathrm{C}$ higher than that of case 2 . As to case 4 , in which 0.08 volume fraction of the proposed HNF is adopted, rises in $\mathrm{T}_{\mathrm{g}}$ and $\mathrm{T}_{\mathrm{f}}$ are witnessed. In this case,

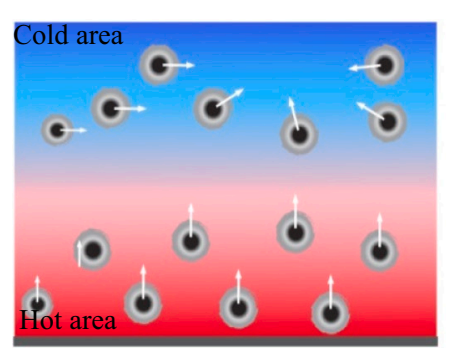

Thermophoresis effect

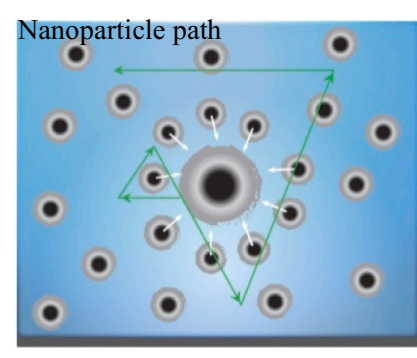

Brownian motion

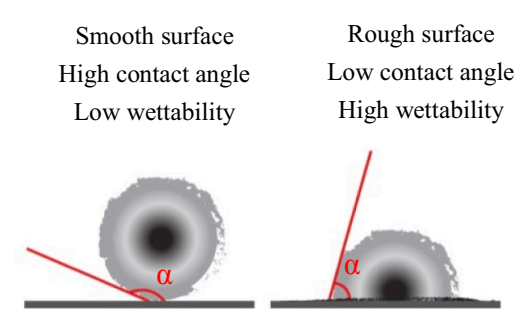

Roughness and wettability

Fig. 7. Schematic of nanoscale phenomena taking place inside the NF leading to augmenting the SS evaporation rate. 

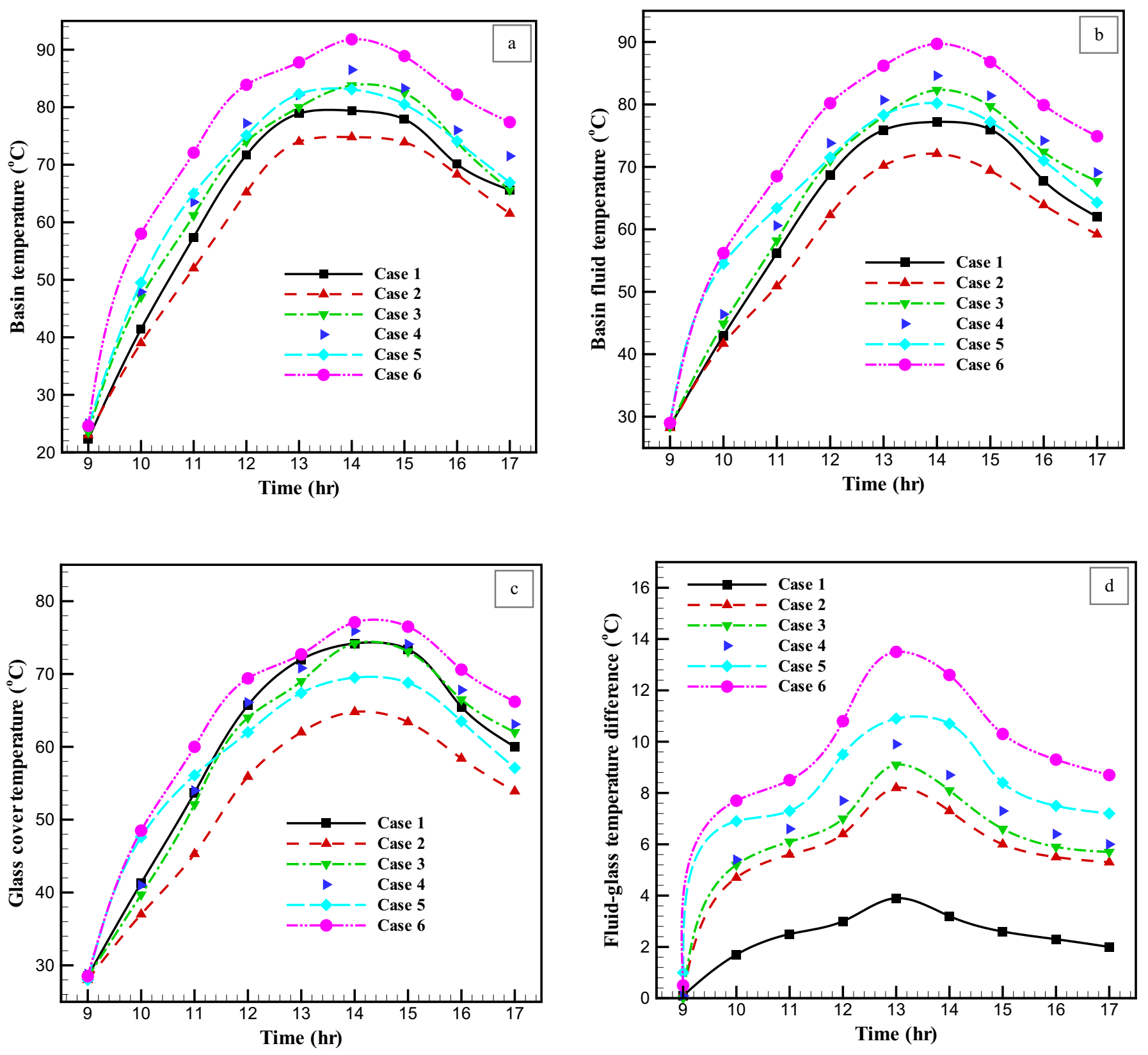

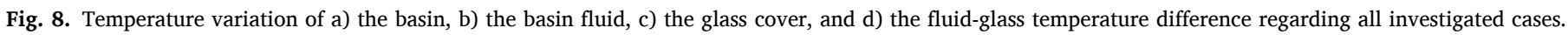

$\Delta \mathrm{T}_{\mathrm{f}-\mathrm{g}}$ varies between $0.1{ }^{\circ} \mathrm{C}$ and $9.9{ }^{\circ} \mathrm{C}$ indicating the heat transfer characteristics improvement compared to the previous cases. The maximum $\mathrm{T}_{\mathrm{f}}$ is roughly $2.3^{\circ} \mathrm{C}$ more than that of case 3 . Additionally, the maximum amounts of $\Delta \mathrm{T}_{\mathrm{f}-\mathrm{g}}$ regarding cases 3 and $4($ at $1: 00 \mathrm{pm})$ are $0.9^{\circ} \mathrm{C}$ and $1.7^{\circ} \mathrm{C}$ more than that of case 2 ; respectively, demonstrating that the $\Delta \mathrm{T}_{\mathrm{f}-\mathrm{g}}$ increase rate at 0.04 volume fraction of the $\mathrm{Ag} @ \mathrm{Fe}_{3} \mathrm{O}_{4}$ / DW HNF is more than that in 0.08 volumetric fraction of the $\mathrm{Ag} @ \mathrm{Fe}_{3} \mathrm{O}_{4} /$ DW HNF. Furthermore, the interpretations relating to the thermal characteristics of cases 5 and 6 (the two ICETCTCCSS types) will be comprehensively presented in Section 5.2.4.

\subsubsection{Performance analysis}

Fig. 9 (a) represents the hourly productivity and hourly energy efficiency of different cases throughout the day. As moving towards the solar noon (highest solar radiation) both hourly productivity and hourly energy efficiency of the SSs increase. Fig. 9 (a) shows that the highest hourly productivity and hourly energy efficiency occur at 2:00 pm; however, Fig. 6 indicated that the highest solar radiation is at 1:00. This delay in producing the highest distilled water and the highest solar radiation is due to the fluid evaporation-condensation mechanism. When the radiation strikes the fluid, a specific time interval is required to let the fluid evaporate. Hence, there will be a delay between the highest radiation and the highest productivity of SS. Fig. 9 (a) indicates that the maximum productivity and the highest energy efficiency of TCCSS (case 2) are about $400 \mathrm{~mL}$ and $20.94 \%$ higher than those of the TSS (case 1), respectively. Regarding case 3 (applying $0.04 \mathrm{VF}$ of the nanoparticles), the highest productivity and energy efficiency increased up to $19.2 \%$ and $18.1 \%$; respectively, compared to those of case 2 . Also, as to case 4 (utilizing $\mathrm{Ag} @ \mathrm{Fe}_{3} \mathrm{O}_{4} / \mathrm{DW} \mathrm{HNF}$ at 0.08 volume concentration), these parameters rose up to $293 \mathrm{~mL}$ and $14.6 \%$ compared to those of case 2 . As a whole, it was observed that using the $\mathrm{Ag} @ \mathrm{Fe}_{3} \mathrm{O}_{4} / \mathrm{DW} \mathrm{HNF}$ has a positive impact on the thermal performance of SSs.

Furthermore, Fig. 9 (b) illustrates the daily productivity and daily energy efficiency of different cases during the days of experiments. As 
Table 3

Temperatures of different components regarding all investigated cases.

\begin{tabular}{|c|c|c|c|c|c|}
\hline Testing case & Time (h) & $\mathrm{T}_{\mathrm{b}}\left({ }^{\circ} \mathrm{C}\right)$ & $\mathrm{T}_{\mathrm{f}}\left({ }^{\circ} \mathrm{C}\right)$ & $\mathrm{T}_{\mathrm{g}}\left({ }^{\circ} \mathrm{C}\right)$ & $\Delta \mathrm{T}_{\mathrm{f}-\mathrm{g}}\left({ }^{\circ} \mathrm{C}\right)$ \\
\hline \multirow{9}{*}{ Case 1} & 9 & 22.3 & 28.5 & 28.5 & 0.1 \\
\hline & 10 & 41.4 & 43 & 41.3 & 1.7 \\
\hline & 11 & 57.4 & 56.2 & 53.7 & 2.5 \\
\hline & 12 & 71.7 & 68.7 & 65.7 & 3 \\
\hline & 13 & 78.9 & 75.9 & 72 & 3.9 \\
\hline & 14 & 79.4 & 77.2 & 74.2 & 3.2 \\
\hline & 15 & 77.9 & 76 & 73.4 & 2.6 \\
\hline & 16 & 70.1 & 67.8 & 65.5 & 2.3 \\
\hline & 17 & 65.6 & 62 & 60 & 2 \\
\hline \multirow{9}{*}{ Case 2} & 9 & 23 & 28.2 & 28 & 0.2 \\
\hline & 10 & 39 & 41.7 & 37 & 4.7 \\
\hline & 11 & 52 & 50.9 & 45.3 & 5.6 \\
\hline & 12 & 65.2 & 62.3 & 55.9 & 6.4 \\
\hline & 13 & 74 & 70.2 & 62 & 8.2 \\
\hline & 14 & 74.8 & 72.1 & 64.8 & 7.3 \\
\hline & 15 & 73.9 & 69.4 & 63.4 & 6 \\
\hline & 16 & 68.3 & 63.9 & 58.4 & 5.5 \\
\hline & 17 & 61.5 & 59.2 & 53.9 & 5.3 \\
\hline \multirow{9}{*}{ Case 3} & 9 & 23.5 & 28.4 & 28.4 & 0 \\
\hline & 10 & 47 & 44.9 & 39.7 & 5.2 \\
\hline & 11 & 61.2 & 58.2 & 52.1 & 6.1 \\
\hline & 12 & 74 & 71 & 64 & 7 \\
\hline & 13 & 80 & 78.1 & 69 & 9.1 \\
\hline & 14 & 83.8 & 82.3 & 74.2 & 8.1 \\
\hline & 15 & 82.5 & 79.7 & 73.1 & 6.6 \\
\hline & 16 & 73.9 & 72.4 & 66.5 & 5.9 \\
\hline & 17 & 65.6 & 67.7 & 62 & 5.7 \\
\hline \multirow{9}{*}{ Case 4} & 9 & 25 & 28.9 & 28.8 & 0.1 \\
\hline & 10 & 47.9 & 46.4 & 41 & 5.4 \\
\hline & 11 & 63.5 & 60.6 & 54 & 6.6 \\
\hline & 12 & 77.2 & 73.8 & 66.1 & 7.7 \\
\hline & 13 & 82.1 & 80.7 & 70.8 & 9.9 \\
\hline & 14 & 86.5 & 84.6 & 75.9 & 8.7 \\
\hline & 15 & 83.3 & 81.4 & 74.1 & 7.3 \\
\hline & 16 & 76 & 74.2 & 67.8 & 6.4 \\
\hline & 17 & 71.5 & 69.1 & 63.1 & 6 \\
\hline \multirow{9}{*}{ Case 5} & 9 & 24.5 & - & 28 & - \\
\hline & 10 & 49.5 & 54.5 & 47.6 & 6.9 \\
\hline & 11 & 65 & 63.4 & 56.1 & 7.3 \\
\hline & 12 & 75.1 & 71.5 & 62 & 9.5 \\
\hline & 13 & 82.3 & 78.3 & 67.4 & 10.9 \\
\hline & 14 & 83.1 & 80.2 & 69.5 & 10.7 \\
\hline & 15 & 80.5 & 77.2 & 68.8 & 8.4 \\
\hline & 16 & 74.1 & 71 & 63.5 & 7.5 \\
\hline & 17 & 66.9 & 64.3 & 57.1 & 7.2 \\
\hline \multirow{9}{*}{ Case 6} & 9 & 24.6 & - & 28.5 & - \\
\hline & 10 & 58 & 56.2 & 48.5 & 7.7 \\
\hline & 11 & 72.1 & 68.5 & 60 & 8.5 \\
\hline & 12 & 83.9 & 80.2 & 69.4 & 10.8 \\
\hline & 13 & 87.8 & 86.2 & 72.7 & 13.5 \\
\hline & 14 & 91.8 & 89.7 & 77.1 & 12.6 \\
\hline & 15 & 88.9 & 86.8 & 76.5 & 10.3 \\
\hline & 16 & 82.2 & 79.9 & 70.6 & 9.3 \\
\hline & 17 & 77.4 & 74.9 & 66.2 & 8.7 \\
\hline
\end{tabular}

seen in Fig. 9 (b), the rate of productivity of case 4 is approximately $59.6 \%, 18 \%$, and $8.9 \%$ more than that for cases 1,2 , and 3 , respectively. On the other hand, the increase rate of energy efficiency for case 4 in comparison to that of cases 1,2 , and 3 is about $59.4 \%, 17.1 \%$, and $8.7 \%$, successively.

\subsubsection{On the role concentrating evacuated tube collector}

In this section, the impact of integrating the CETC to the TCCSS with water (case 5) and 0.08 volume fraction of the $\mathrm{Ag} @ \mathrm{Fe}_{3} \mathrm{O}_{4} / \mathrm{DW} \mathrm{HNF}$ (case 6) on the productivity and thermal efficiency of hybrid solar thermal-desalination system has been experimentally examined. It ought to be mentioned that the fluid was initially preheated through the CETC. Then, the fluid entered the floater at 9:15 am and; subsequently, it entered the TCCSS. Hence, the first time of reporting the ICETCTCCSS performance data was at 10:00 am.

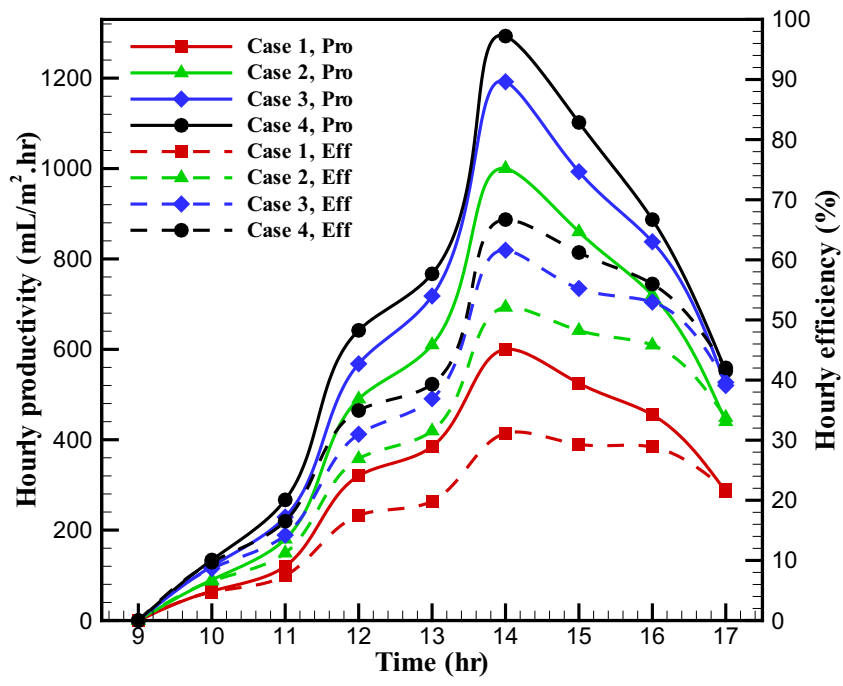

(a)

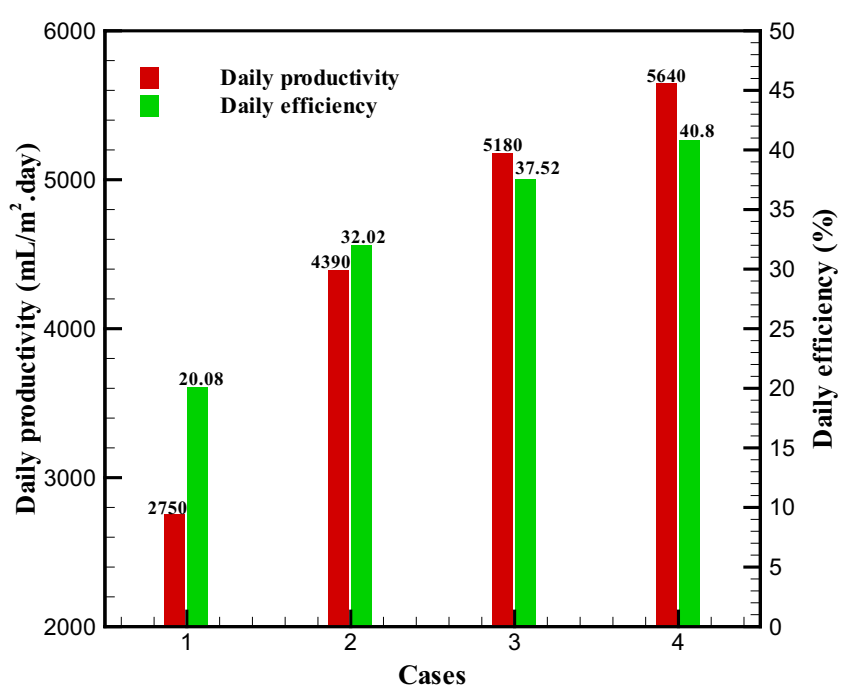

(b)

Fig. 9. (a) Hourly productivity and hourly energy efficiency of the cases 1-4 (b) Daily productivity and daily energy efficiency of the cases 1-4.

5.2.4.1. Temperature variation. As it is demonstrated in Table 3 , the fluid temperature in the ICETCTCCSS experienced a jump at 10:00 am compared to that in the TCCSS and this is due to the preheated inlet fluid entering the basin from the beginning of experiment. Moreover, Table 3 represents that regarding case 5 , the maximum fluid temperature at $1: 00 \mathrm{pm}$ and the maximum $\Delta \mathrm{T}_{\mathrm{f}-\mathrm{g}}$ at 2:00 pm were respectively $9^{\circ} \mathrm{C}$ and $2.7^{\circ} \mathrm{C}$ more than those for case 2 , which is the influence of CETC on the operational temperature of active TCCSS using water as the working fluid. In terms of case 6 , it is shown that these figures $\left(T_{\mathrm{f}}\right.$ and $\left.\Delta \mathrm{T}_{\mathrm{f}-\mathrm{g}}\right)$ enhanced by $5.1{ }^{\circ} \mathrm{C}$ and $3.6{ }^{\circ} \mathrm{C}$ in comparison with case 4 , which is indicating how much CETC affects the thermal characteristics of active TCCSS utilizing the $\mathrm{Ag} @ \mathrm{Fe}_{3} \mathrm{O}_{4} / \mathrm{DW} \mathrm{HNF}$ at 0.08 volume fraction as the heat transfer fluid. As a whole, it was concluded that coupling the CETC can retrofit the TCCSS in all operational conditions.

5.2.4.2. Performance analysis. Fig. 10 (a) illustrates the hourly productivity and the hourly thermal efficiency regarding cases 2, 5, 4, and 6 . As shown in this figure, with increasing the solar radiation, the productivity and the energy efficiency of all types of SSs increase up to solar 


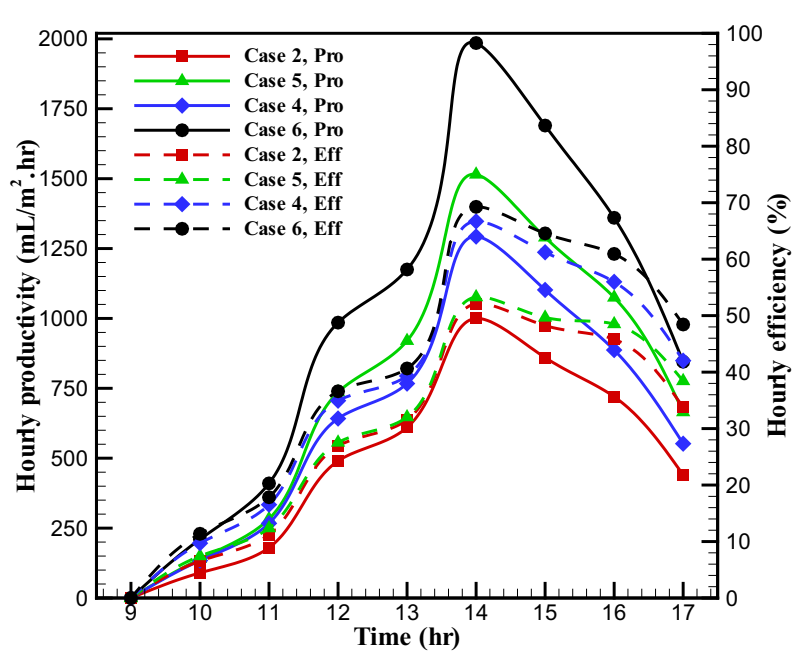

(a)

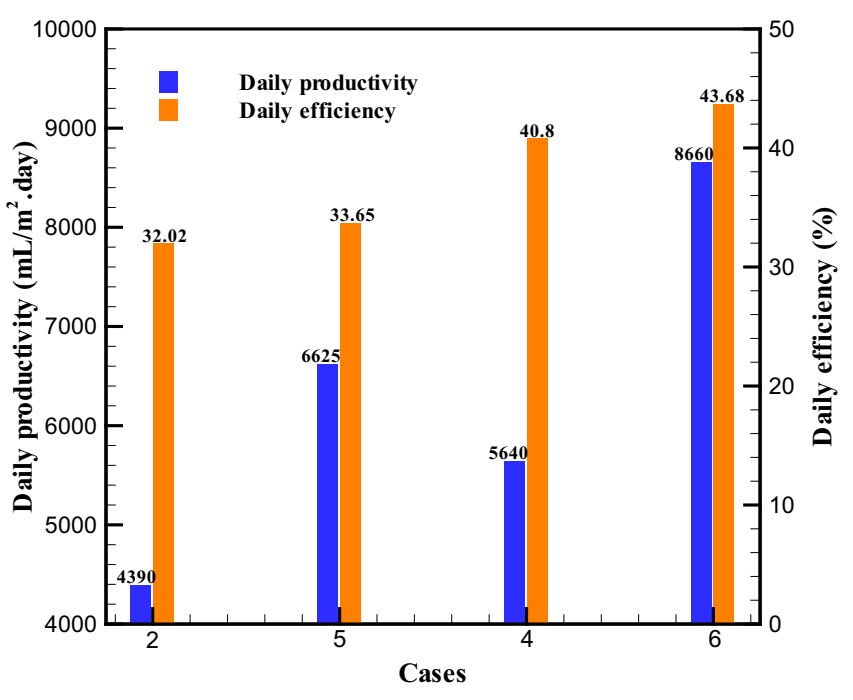

(b)

Fig. 10. (a) Daily productivity and daily energy efficiency of the cases $2,4,5$, and 6 (b) Daily productivity and daily energy efficiency of the cases $2,4,5$, and 6.

noon time and after that, these performance parameters decline. The highest hourly efficiency and hourly productivity of the proposed cases have occurred at 2:00 pm. In terms of case 5, which is the ICETCTCCSS with water as the working fluid, the maximum hourly productivity and the highest energy efficiency are $515\left(\mathrm{~mL} / \mathrm{m}^{2} . \mathrm{h}\right)$ and $1.2 \%$ more than those of the case 2 (TCCSS), respectively. It is worth mentioning that the productivity of case 5 is about $51.5 \%$ more than that of case 2 ; however, the increase rate of energy efficiency is only $2.3 \%$ compared to that of case 2 . This result is due to the fact that in the denominator of SS efficiency formula (Eq. (2)), a considerable amount of CETC surface $\left(\mathrm{A}_{c}\right)$ has been added. In addition, as to case 6, in which the $\mathrm{Ag} @ \mathrm{Fe}_{3} \mathrm{O}_{4} / \mathrm{DW}$ HNF has initially been preheated through the CETC and; then, enters the TCCSS, the maximum hourly productivity and hourly efficiency were respectively $692\left(\mathrm{~mL} / \mathrm{m}^{2} . \mathrm{h}\right)$ and $2.57 \%$ more than those of case 4 . Having the results appeared for comparison, the performance of ICETCTCCSS with the HNF is more than that of the ICETCTCCSS with water as the heat transfer fluid.

Furthermore, Fig. 10 (b) indicates a bar chart related to the daily productivity and daily efficiency regarding cases $2,5,4$, and 6 , and compares the results. As illustrated in Fig. 10 (b), the daily productivity and daily efficiency of case 5 are respectively $2235\left(\mathrm{~mL} / \mathrm{m}^{2}\right.$.day) and $1.63 \%$ more than those of case 2 , which reveals that the increase rate of these performance parameters are successively $50.9 \%$ and $5.09 \%$ in comparison with case 2 . When cases 4 and 6 appear for comparison, the daily productivity and daily efficiency of case 6 are respectively 3020 $\left(\mathrm{mL} / \mathrm{m}^{2}\right.$.day) and $2.88 \%$ more than those of case 4 . Hence, it can be concluded that integrating the CETC with the TCCSS enhances both productivity and SS efficiency in all circumstances.

\subsubsection{Investigation of the distilled water quality}

In the present study, the $\mathrm{pH}$ value and the amount of solid particles were assessed so as for investigating the qualitative physical properties of the produced distilled water. The TDS is one of the significant characteristics in denoting the taste and potability degree of water demonstrating presence or absence of the various mineral saults and the ions, such as chloride, sulfate, phosphate, calcium, magnesium, potassium, and iron in water. Before testing the quality of distilled water, the sampling containers were initially washed through the nitric acid and then washed with the tap water. Next, the distilled water was poured into the sampling containers for the quality investigation purposes. The $\mathrm{pH}$ amount of potable water ought to be within 6 to 8 [49] and the preferable TDS value for the drinkable water should be within 70 and $300 \mathrm{ppm}$ to not seem as brackish water [50]. In this research, the $\mathrm{pH}$ value of distilled water was in the range of 6.5 to 7 as well as the hardness of distilled water (TDS value) varied within 150-200 ppm. Fig. 11 (a) and (b) successively illustrate the investigations of $\mathrm{pH}$ and TDS values in this project.

\subsection{Economic analysis}

According to researches, there are about 300 sunny days in Iran each year [51]. Since, the cost of electricity for running the present ICETCTCCSS is about $0.0006 \$ / 1 / \mathrm{m}^{2}$, it is negligible and it is not regarded in the economic analysis. On the other hand, the value of industrially produced potable water in the country of origin (Iran) is 0.1 $\$ / \mathrm{L}$. Table 4 shows the economic results of different cases of solar stills. From an economical viewpoint, it can be concluded that the average amount of CPL for all investigated cases is roughly $1 / 5$ of that of the industrially produced freshwater with reasonable PBP values. Moreover, when different types of the constructed SSs in this work appear for comparison, it might be assumed that case 1 possessing a low PBP of 332 days and the CPL Of 0.017 is economically more favorable than the other cases; however, it has to be noticed that the productivity of case 1 is too low to supply even domestic freshwater uses and the other part of the potable water demand needs to be purchased with the CPL of $0.1 \$ / \mathrm{L} /$ $\mathrm{m}^{2}$, which will be quite costly. In terms of cases 2,3 , and 4, the TCC and proposed HNF have augmented the CPL and the PBP is about 450 days. Furthermore, regarding cases 5 and 6, even though the cost of NF used in case 6 is higher than that of water used in case 5 ; however, it is the much higher productivity of case 6 , which has led to a less CPL and PBP values compared to those of case $5\left(0.019 \$ / \mathrm{L} / \mathrm{m}^{2}\right.$ and 369 days for case 6 versus $0.2 \$ / \mathrm{L} / \mathrm{m}^{2}$ and 394 days for case 5 ).

If looked from another angle, let's assume a family of 5 tends to utilize one of the proposed cases for supplying the potable water demand. Typically, each individual uses $2 \mathrm{~L}$ of disinfected freshwater on a daily basis [52]; hence, $10 \mathrm{~L}$ of freshwater is required for the investigated family daily potable water demand. If case 1 is supposed to be used, $2750 \mathrm{~mL}$ will be produced by the TSS and the remaining $7250 \mathrm{~mL}$ must be purchased at $0.1 \$ / \mathrm{L} / \mathrm{m}^{2}$; hence, the capital cost will be 0.771 $\$ / \mathrm{L} / \mathrm{m}^{2}$. However, if case 6 is supposed to be applied, $8660 \mathrm{~mL}$ of freshwater will be produced by the ICETCTCCSS and $1340 \mathrm{~mL}$ has to be purchased. Thereafter, the capital cost will be $0.298 \$ / \mathrm{L} / \mathrm{m}^{2}$. Solar fraction is defined as ratio of the output of solar system to the amount of energy demand. If solar fraction of 1 is applied, $3.63 \mathrm{~m}^{2}$ of case 1 is required to supply the potable water demand of a family of 5 implying 

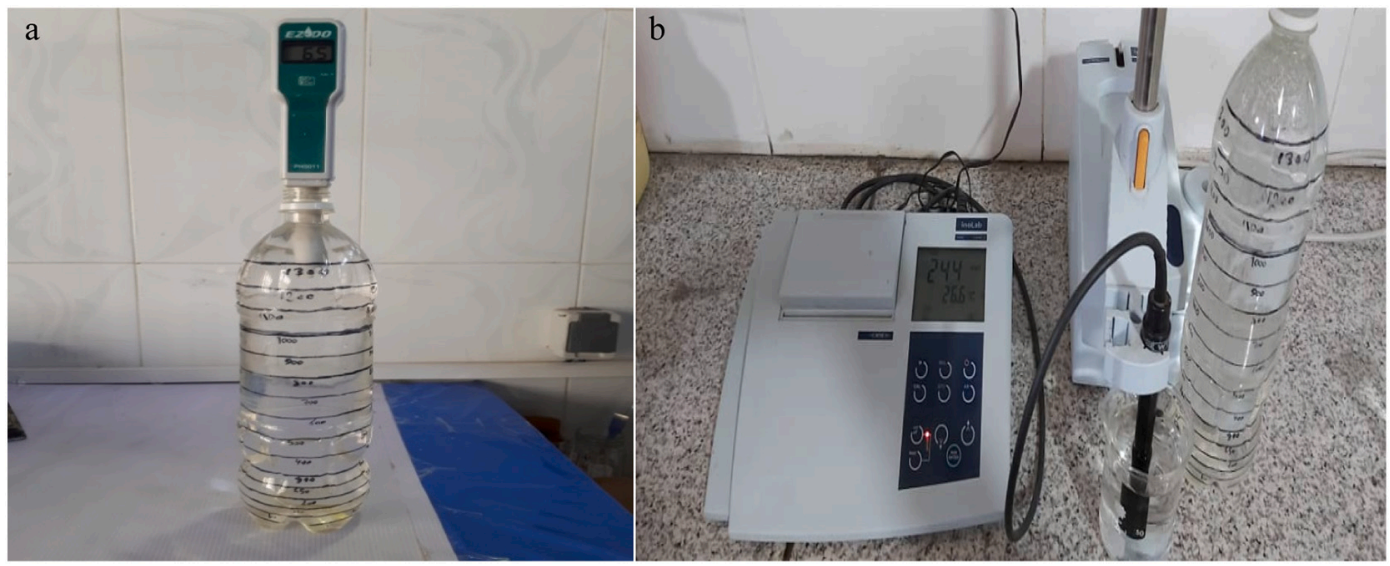

Fig. 11. (a) $\mathrm{pH}$ of the distilled water, (b) TDS measurement of the distilled water.

Table 4

Values of the cost analysis parameters.

\begin{tabular}{|c|c|c|c|c|c|c|c|c|c|c|c|c|}
\hline Testing case & $\mathrm{P}$ & $\mathrm{R}$ & $\mathrm{RCF}$ & $\mathrm{AFC}$ & RFF & ARV & AMC & ATC & $\left(\dot{m}_{e v}\right)_{d}\left(\mathrm{~mL} / \mathrm{m}^{2}\right)$ & $\mathrm{CPL}\left(\$ / \mathrm{L} / \mathrm{m}^{2}\right)$ & $\mathrm{CF}$ & PBP (Day) \\
\hline Case 1 & 65 & 13 & 0.2 & 13 & 0.05 & 0.65 & 1.95 & 14.3 & 2750 & 0.017 & 82.5 & 332 \\
\hline Case 2 & 139 & 28 & 0.2 & 28 & 0.05 & 1.4 & 4.2 & 30.8 & 4390 & 0.023 & 131.7 & 437 \\
\hline Case 3 & 164 & 33 & 0.2 & 33 & 0.05 & 1.65 & 4.95 & 36.3 & 5180 & 0.023 & 155.4 & 437 \\
\hline Case 4 & 189 & 38 & 0.2 & 38 & 0.05 & 1.9 & 5.7 & 41.8 & 5640 & 0.024 & 169.2 & 461 \\
\hline Case 5 & 179 & 36 & 0.2 & 36 & 0.05 & 1.8 & 5.4 & 39.6 & 6620 & 0.02 & 198.7 & 394 \\
\hline Case 6 & 229 & 46 & 0.2 & 46 & 0.05 & 2.3 & 6.9 & 50.6 & 8860 & 0.019 & 259.8 & 369 \\
\hline
\end{tabular}

Table 5

Drawing a comparison between the previous similar studies and the present research.

\begin{tabular}{|c|c|c|c|c|c|c|c|}
\hline No. & Authors & $\begin{array}{l}\text { System } \\
\text { type }\end{array}$ & $\begin{array}{l}\text { Study } \\
\text { procedure }\end{array}$ & Work description & $\begin{array}{l}\text { Daily productivity } \\
\left(\mathrm{mL} / \mathrm{m}^{2}\right)\end{array}$ & $\begin{array}{l}\text { Daily } \\
\text { efficiency }\end{array}$ & $\begin{array}{l}\mathrm{CPL} \\
(\$ / \mathrm{L} / \\
\left.\mathrm{m}^{2}\right)\end{array}$ \\
\hline 1. & $\begin{array}{l}\text { Kabeel et al. } \\
\text { [53] }\end{array}$ & Active & Experimental & Using an external condenser and NFs in an SS & 4010 & $\mathrm{~N} / \mathrm{A}$ & 0.05 \\
\hline 2. & $\begin{array}{l}\text { Elango et al. } \\
\text { [54] }\end{array}$ & Passive & Experimental & Using $\mathrm{Al}_{2} \mathrm{O}_{3} / \mathrm{W} \mathrm{NF}$ in an $\mathrm{SS}$ & 3810 & N/A & N/A \\
\hline 3. & $\begin{array}{l}\text { Eltawil and } \\
\text { Omara. [55] }\end{array}$ & Active & Experimental & Using an external condenser and an FPSC integrated with an SS & 6000 & $\mathrm{~N} / \mathrm{A}$ & 0.052 \\
\hline 4. & $\begin{array}{l}\text { Rahbar et al. } \\
\text { [56] }\end{array}$ & Active & Experimental & Utilizing TMs under the basin surface to heat the water inside an SS & 2850 & $18 \%$ & 0142 \\
\hline 5. & $\begin{array}{l}\text { Mahian et al. } \\
\text { [30] }\end{array}$ & Active & Experimental & $\begin{array}{l}\text { Integrating an FPSC with an SS and installing a heat exchanger inside the } \\
\text { basin at } 70{ }^{\circ} \mathrm{C} \mathrm{SiO}_{2} / \mathrm{W} \mathrm{NF}\end{array}$ & 2950 & $36.5 \%$ & $\mathrm{~N} / \mathrm{A}$ \\
\hline 6. & $\begin{array}{l}\text { Shafii et al. } \\
{[6]}\end{array}$ & Active & Experimental & $\begin{array}{l}\text { Integrated an ETC with an SS and employed TMs for using the heat of } \\
\text { evaporation of water to generate electricity to run a fan for forced } \\
\text { convection induction and increasing the condensation rate }\end{array}$ & 6186 & $52 \%$ & 0.013 \\
\hline 7. & $\begin{array}{l}\text { Kabeel et al. } \\
{[57]}\end{array}$ & Active & Experimental & $\begin{array}{l}\text { Utilized a PTC with circulating oil inside a heat exchanger at the bottom } \\
\text { of the basin and using PCM in edge sides of the SS basin }\end{array}$ & 10,770 & $25.73 \%$ & 0.017 \\
\hline 8. & $\begin{array}{l}\text { Sharshir et al. } \\
\text { [32] }\end{array}$ & Passive & Experimental & Integrating an ETC with a pyramid-like SS using carbon black NF & 4300 & $64.5 \%$ & 0.036 \\
\hline 9. & $\begin{array}{l}\text { Shehata et al. } \\
\text { [31] }\end{array}$ & Active & Experimental & Integrating an ETC with an SS using PCM and six ultrasonic humidifiers & 7400 & $32 \%$ & 0.037 \\
\hline 10. & $\begin{array}{l}\text { Parsa et al. } \\
{[26]}\end{array}$ & Active & Experimental & $\begin{array}{l}\text { Utilizing a reflector, using TMs for heating the basin surface and cooling } \\
\text { the external condenser and using } \mathrm{Ag} / \mathrm{W} \mathrm{NF} \text { in an SS. The electric power } \\
\text { consumption of TMs was supplied by photovoltaic panels. }\end{array}$ & 7970 & $25.77 \%$ & N/A \\
\hline 11. & $\begin{array}{l}\text { Hassan et al. } \\
{[58]}\end{array}$ & Active & Experimental & $\begin{array}{l}\text { Integrating an oil-based PTC with an SS employing a serpentine heat } \\
\text { exchanger at the bottom of the basin }\end{array}$ & 9750 & $20 \%$ & 0.019 \\
\hline 12. & $\begin{array}{l}\text { Nazari et al. } \\
{[24]}\end{array}$ & Active & Experimental & $\begin{array}{l}\text { Using a TCC to reduce the glass cover temperature of a single slope SS as } \\
\text { well using } \mathrm{Cu}_{2} \mathrm{O} / \mathrm{W} \text { NF. }\end{array}$ & 5600 & $\mathrm{~N} / \mathrm{A}$ & 0.025 \\
\hline 13. & $\begin{array}{l}\text { Present } \\
\text { research }\end{array}$ & Active & Experimental & $\begin{array}{l}\text { Integrating a CETC with a TCCSS and applying an antibacterial-magnetic } \\
\mathrm{Ag} @ \mathrm{Fe}_{3} \mathrm{O}_{4} / \mathrm{DW} \mathrm{HNF}\end{array}$ & 8660 & $43.68 \%$ & 0.019 \\
\hline
\end{tabular}


the CPL of $0.061 \$ / \mathrm{L} / \mathrm{m}^{2}$; whereas, $1.55 \mathrm{~m}^{2}$ of case 6 is needed for this purpose inferring the CPL of $0.029 \$ / \mathrm{L} / \mathrm{m}^{2}$. Thereby, not only case 6 is economically more desirable, but it occupies less space for operation.

Table 5 illustrates a comparison between the daily productivity, daily energy efficiency, and CPL of current research and those of the previous similar works.

\section{Conclusion}

In this work, the antibacterial-magnetic $\mathrm{Ag} @ \mathrm{Fe}_{3} \mathrm{O}_{4} / \mathrm{DW} \mathrm{HNF}$ at different VFs was applied to a TCCSS and an ICETCTCCSS to enhance the productivity, efficiency, and hygiene standards of solar desalination systems. Moreover, an economic analysis was conducted to evaluate the cost-effectiveness of different cases of SSs. The overall results of the current research can be listed as below:

- The highest ambient and fluid temperatures occurred with a delay (at 2:00 pm) after the highest solar radiation intensity time (at 1:00 pm) due to the time-dependent nature of photothermal process. This process also holds for the maximum $\Delta \mathrm{T}_{\mathrm{f}-\mathrm{g}}$ time (at 1:00 pm) and the highest productivity time (at 2:00 $\mathrm{pm}$ ).

- The phenomena, such as the thermophoresis effect and the Brownian motion led to improvement of the thermal properties of fluid. Furthermore, enhancement of the basin surface roughness caused a more fluid wettability.

- The maximum daily productivities of cases $1,2,3,4,5$, and 6 were $2750,4390,5180,5640,6625$, and $8660\left(\mathrm{~mL} / \mathrm{m}^{2} . \mathrm{h}\right)$, respectively.

- The highest daily energy efficiencies of cases $1,2,3,4,5$, and 6 were reported as $20.08,32.02,37.52,40.8,33.65$, and $43.68 \%$, respectively. As it can be inferred, integrating the CETC led to reducing the SS efficiency due to the extra absorption area of CETC in Eq. (2); however, using the proposed nanofluid compensated for this impact and enhanced the ICETCTCCSS efficiency by about $10 \%$.

- The cost analysis clearly showed that the use of nanoparticles will increase the CPL value up to $0.024\left(\$ / \mathrm{L} / \mathrm{m}^{2}\right)$; however, integrating the TCCSS with a CETC using $\mathrm{Ag} @ \mathrm{Fe}_{3} \mathrm{O}_{4} / \mathrm{DW}$ HNF can increase the distilled water production leading to presenting the CPL value of $0.019\left(\$ / \mathrm{L} / \mathrm{m}^{2}\right)$. Also, the PBP for the proposed ICETCTCCSS is about one year.

Further researches can be implemented on integrating this TCCSS with PCMs in order to store the heat for a distilled water production during weak solar radiation times. Furthermore, the CETC can be incorporated into the TCCSS as a single unit to occupy less space.

\section{Funding information}

There was no funding support for this research.

\section{CRediT authorship contribution statement}

- Gholamabbas Sadeghi: Conceptualization, methodology, resources, implementing the experiments, writing the original draft, and conducting a commentary revision

- Saeed Nazari: Supervising, reviewing and editing the revised manuscript, data analysis, and validation of results

\section{Declaration of competing interest}

I declare that there does not exist any conflict of interest for this research.

\section{References}

[1] J.-K. Sun, Y. Jiang, X. Zhong, J.-S. Hu, L.-J. Wan, Three-dimensional nanostructured electrodes for efficient quantum-dot-sensitized solar cells, Nano Energy 32 (2017) 130-156.

[2] R. Sood, S. Cavaliere, D.J. Jones, J. Rozière, Electrospun nanofibre composite polymer electrolyte fuel cell and electrolysis membranes, Nano Energy 26 (2016) $729-745$.

[3] X. Wang, J. Song, J. Liu, Z.L. Wang, Direct-current nanogenerator driven by ultrasonic waves, Science. 316 (5821) (2007) 102-105.

[4] Z.L. Wang, J. Song, Piezoelectric nanogenerators based on zinc oxide nanowire arrays, Science. 312 (5771) (2006) 242-246.

[5] J. Navas, A. Sánchez-Coronilla, E.I. Martín, M. Teruel, J.J. Gallardo, T. Aguilar, et al., On the enhancement of heat transfer fluid for concentrating solar power using $\mathrm{Cu}$ and Ni nanofluids: an experimental and molecular dynamics study, Nano Energy 27 (2016) 213-224.

[6] M.B. Shafii, M. Shahmohamadi, M. Faegh, H. Sadrhosseini, Examination of a novel solar still equipped with evacuated tube collectors and thermoelectric modules, Desalination. 382 (2016) 21-27.

[7] G. Sadeghi, H. Safarzadeh, M. Bahiraei, M. Ameri, M. Raziani, Comparative study of air and argon gases between cover and absorber coil in a cylindrical solar water heater: an experimental study, Renew. Energy 135 (2019) 426-436.

[8] G. Sadeghi, H. Safarzadeh, M. Ameri, Experimental and numerical investigations on performance of evacuated tube solar collectors with parabolic concentrator, applying synthesized Cu2O/distilled water nanofluid, Energy for Sustainable Development. 48 (2019) 88-106.

[9] M. Jowzi, F. Veysi, G. Sadeghi, Experimental and numerical investigations on the thermal performance of a modified evacuated tube solar collector: effect of the bypass tube, Sol. Energy 183 (2019) 725-737.

[10] A. Abdullah, F. Essa, H.B. Bacha, Z. Omara, Improving the trays solar still performance using reflectors and phase change material with nanoparticles, Journal of Energy Storage. 31 (2020) 101744.

[11] Z. Omara, A. Kabeel, F. Essa, Effect of using nanofluids and providing vacuum on the yield of corrugated wick solar still, Energy Convers. Manag. 103 (2015) 965-972.

[12] Z. Omara, A. Kabeel, A. Abdullah, F. Essa, Experimental investigation of corrugated absorber solar still with wick and reflectors, Desalination. 381 (2016) 111-116.

[13] F. Essa, M. Abd Elaziz, A.H. Elsheikh, An enhanced productivity prediction model of active solar still using artificial neural network and Harris Hawks optimizer, Appl. Therm. Eng. 170 (2020) 115020.

[14] S. Shanmugan, F. Essa, Experimental study on single slope single basin solar still using TiO2 nano layer for natural clean water invention, Journal of Energy Storage. 30 (2020) 101522.

[15] A. Abdullah, F. Essa, Z. Omara, Y. Rashid, L. Hadj-Taieb, G. Abdelaziz, et al., Rotating-drum solar still with enhanced evaporation and condensation techniques: comprehensive study, Energy Convers. Manag. 199 (2019) 112024.

[16] M.M. Thalib, A.M. Manokar, F.A. Essa, N. Vasimalai, R. Sathyamurthy, F.P. Garcia Marquez, Comparative study of tubular solar stills with phase change material and nano-enhanced phase change material, Energies. 13 (15) (2020) 3989.

[17] M. Porta-Gándara, J. Fernández-Zayas, N. Chargoy-del-Valle, Solar still distillation enhancement through water surface perturbation, Sol. Energy 196 (2020) $312-318$.

[18] S. Nazari, H. Safarzadeh, M. Bahiraei, Experimental and analytical investigations of productivity, energy and exergy efficiency of a single slope solar still enhanced with thermoelectric channel and nanofluid, Renew. Energy 135 (2019) 729-744.

[19] S. Shoeibi, N. Rahbar, A.A. Esfahlani, H. Kargarsharifabad, Application of simultaneous thermoelectric cooling and heating to improve the performance of a solar still: an experimental study and exergy analysis, Appl. Energy 263 (2020) 114581.

[20] A. Kabeel, W.M. El-Maghlany, M. Abdelgaied, M.M. Abdel-Aziz, Performance enhancement of pyramid-shaped solar stills using hollow circular fins and phase change materials, Journal of Energy Storage. 31 (2020) 101610.

[21] H. Panchal, D. Mevada, K.K. Sadasivuni, F. Essa, S. Shanmugan, M. Khalid, Experimental and water quality analysis of solar stills with vertical and inclined fins, Groundw. Sustain. Dev. 100410 (2020).

[22] P. Zanganeh, A.S. Goharrizi, S. Ayatollahi, M. Feilizadeh, Nano-coated condensation surfaces enhanced the productivity of the single-slope solar still by changing the condensation mechanism, J. Clean. Prod. 121758 (2020).

[23] P. Zanganeh, A.S. Goharrizi, S. Ayatollahi, M. Feilizadeh, H. Dashti, Efficiency improvement of solar stills through wettability alteration of the condensation surface: an experimental study, Appl. Energy 268 (2020) 114923.

[24] S. Nazari, H. Safarzadeh, M. Bahiraei, Performance improvement of a single slope solar still by employing thermoelectric cooling channel and copper oxide nanofluid: an experimental study, J. Clean. Prod. 208 (2019) 1041-1052.

[25] G.B. Balachandran, P.W. David, P.V. Chellam, M.N.A. Ali, V. Radhakrishnan, R. Balamurugan, et al., Rehash of cooked oil for the palatable water production using single slope solar still, Fuel. 271 (2020) 117613.

[26] S.M. Parsa, A. Rahbar, M. Koleini, S. Aberoumand, M. Afrand, M. Amidpour, A renewable energy-driven thermoelectric-utilized solar still with external condenser loaded by silver/nanofluid for simultaneously water disinfection and desalination, Desalination. 480 (2020) 114354

[27] S. Kumar, A. Dubey, G. Tiwari, A solar still augmented with an evacuated tube collector in forced mode, Desalination. 347 (2014) 15-24.

[28] M.J. Abbaspour, M. Faegh, M.B. Shafii, Experimental examination of a natural vacuum desalination system integrated with evacuated tube collectors, Desalination. 467 (2019) 79-85. 
[29] M. Fathy, H. Hassan, M.S. Ahmed, Experimental study on the effect of coupling parabolic trough collector with double slope solar still on its performance, Sol. Energy 163 (2018) 54-61.

[30] O. Mahian, A. Kianifar, S.Z. Heris, D. Wen, A.Z. Sahin, S. Wongwises, Nanofluids effects on the evaporation rate in a solar still equipped with a heat exchanger, Nano Energy 36 (2017) 134-155.

[31] A.I. Shehata, A. Kabeel, M.M.K. Dawood, A.M. Elharidi, A. Abd Elsalam, K. Ramzy, et al., Enhancement of the productivity for single solar still with ultrasonic humidifier combined with evacuated solar collector: an experimental study, Energy Convers. Manag. 208 (2020) 112592.

[32] S.W. Sharshir, A. Kandeal, M. Ismail, G.B. Abdelaziz, A. Kabeel, N. Yang, Augmentation of a pyramid solar still performance using evacuated tubes and nanofluid: experimental approach, Appl. Therm. Eng. 160 (2019) 113997.

[33] N.T. Alwan, S. Shcheklein, O. Ali, Experimental investigation of modified solar still integrated with solar collector, Case Studies in Thermal Engineering. 100614 (2020).

[34] H. Panchal, S. Hishan, R. Rahim, K.K. Sadasivuni, Solar still with evacuated tubes and calcium stones to enhance the yield: an experimental investigation, Process. Saf. Environ. Prot. 42 (2020) 150-155.

[35] J. Madiouli, A. Lashin, I. Shigidi, I.A. Badruddin, A. Kessentini, Experimental study and evaluation of single slope solar still combined with flat plate collector, parabolic trough and packed bed, Sol. Energy 196 (2020) 358-366.

[36] O. Bait, Direct and indirect solar-powered desalination processes loaded with nanoparticles: a review, Sustainable Energy Technologies and Assessments. 37 (2020) 100597.

[37] A. Siricharoenpanich, S. Wiriyasart, A. Srichat, P. Naphon, Thermal cooling system with $\mathrm{Ag} / \mathrm{Fe} 3 \mathrm{O} 4$ nanofluids mixture as coolant for electronic devices cooling, Case Studies in Thermal Engineering. 100641 (2020).

[38] J. Cai, X. Hu, B. Xiao, Y. Zhou, W. Wei, Recent developments on fractal-based approaches to nanofluids and nanoparticle aggregation, Int. J. Heat Mass Transf. 105 (2017) 623-637.

[39] M. Bahiraei, S. Nazari, H. Moayedi, H. Safarzadeh, Using neural network optimized by imperialist competition method and genetic algorithm to predict water productivity of a nanofluid-based solar still equipped with thermoelectric modules, Powder Technol. 366 (2020) 571-586.

[40] G. Sadeghi, A.L. Pisello, H. Safarzadeh, M. Poorhossein, M. Jowzi, On the effect of storage tank type on the performance of evacuated tube solar collectors: solar radiation prediction analysis and case study, Energy. 117331 (2020).

[41] K. Chopra, V. Tyagi, A.K. Pathak, A. Pandey, A. Sari, Experimental performance evaluation of a novel designed phase change material integrated manifold heat pipe evacuated tube solar collector system, Energy Convers. Manag. 198 (2019) 111896.

[42] E.E. Michaelides, Transport properties of nanofluids. A critical review, Journal of Non-Equilibrium Thermodynamics. 38 (1) (2013) 1-79.
[43] Brown R. XXVII, A brief account of microscopical observations made in the months of June, July and August 1827, on the particles contained in the pollen of plants; and on the general existence of active molecules in organic and inorganic bodies, The Philosophical Magazine. 4 (21) (1828) 161-173.

[44] E.E.S. Michaelides, Heat and Mass Transfer in Particulate Suspensions: Springer Science \& Business Media, 2013.

[45] G. Sadeghi, S. Nazari, M. Ameri, F. Shama, Energy and exergy evaluation of the evacuated tube solar collector using Cu2O/water nanofluid utilizing ANN methods, Sustainable Energy Technologies and Assessments. 37 (2020) 100578.

[46] Y. He, Y. Jin, H. Chen, Y. Ding, D. Cang, H. Lu, Heat transfer and flow behaviour of aqueous suspensions of $\mathrm{TiO} 2$ nanoparticles (nanofluids) flowing upward through a vertical pipe, Int. J. Heat Mass Transf. 50 (11-12) (2007) 2272-2281.

[47] R.N. Wenzel, Resistance of solid surfaces to wetting by water, Ind. Eng. Chem. 28 (8) (1936) 988-994.

[48] D. Gloss, H. Herwig, Wall roughness effects in laminar flows: an often ignored though significant issue, Exp. Fluids 49 (2) (2010) 461-470.

[49] Raut V, Shelke S. Wireless acquisition system for water quality monitoring. Conference Wireless acquisition system for water quality monitoring. IEEE, p. $371-4$.

[50] N. Kumar, A.A. Mahessar, S.A. Memon, K. Ansari, A.L. Qureshi, Impact assessment of groundwater quality using WQI and geospatial tools: a case study of Islamkot, Tharparkar, Pakistan, Engineering, Technology \& Applied Science Research. 10 (1) (2020) 5288-5294.

[51] G. Najafi, B. Ghobadian, R. Mamat, T. Yusaf, W. Azmi, Solar energy in Iran: current state and outlook, Renew. Sust. Energ. Rev. 49 (2015) 931-942.

[52] F.D. Miller, Water consumption and demand measurements for single-family households, J. Environ. Health (1987) 13-17.

[53] A. Kabeel, Z. Omara, F. Essa, Enhancement of modified solar still integrated with external condenser using nanofluids: an experimental approach, Energy Convers. Manag. 78 (2014) 493-498.

[54] T. Elango, A. Kannan, K.K. Murugavel, Performance study on single basin single slope solar still with different water nanofluids, Desalination. 360 (2015) 45-51.

[55] M.A. Eltawil, Z. Omara, Enhancing the solar still performance using solar photovoltaic, flat plate collector and hot air, Desalination. 349 (2014) 1-9.

[56] N. Rahbar, A. Gharaiian, S. Rashidi, Exergy and economic analysis for a double slope solar still equipped by thermoelectric heating modules-an experimental investigation, Desalination. 420 (2017) 106-113.

[57] A. Kabeel, M. Abdelgaied, Observational study of modified solar still coupled with oil serpentine loop from cylindrical parabolic concentrator and phase changing material under basin, Sol. Energy 144 (2017) 71-78.

[58] H. Hassan, M.S. Ahmed, M. Fathy, M.S. Yousef, Impact of salty water medium and condenser on the performance of single acting solar still incorporated with parabolic trough collector, Desalination. 480 (2020) 114324. 